
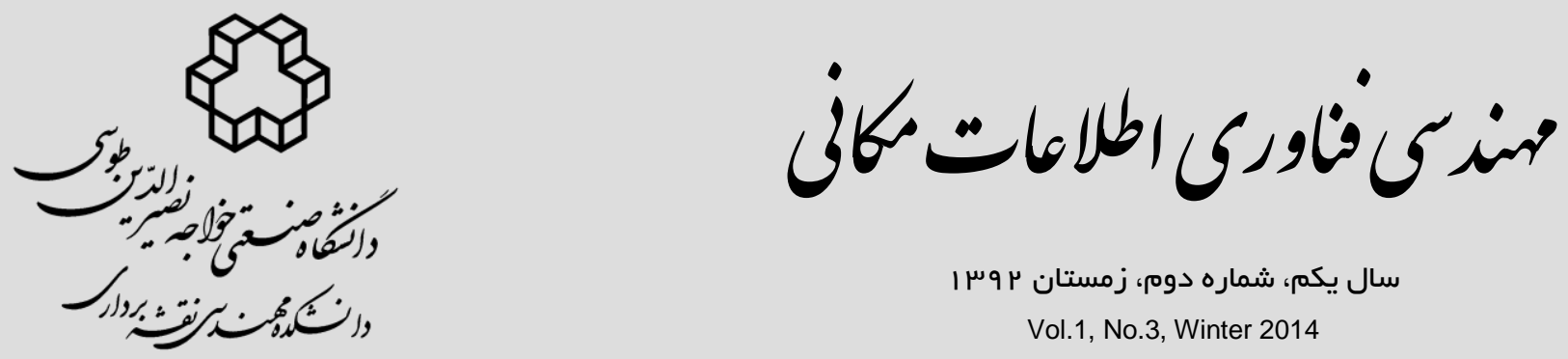

جينش بهينه منابع انتشار امواج الكترومغناطيسى براى دستيابى به بهترين يوشش كيفى

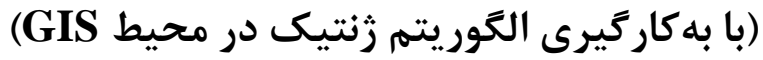

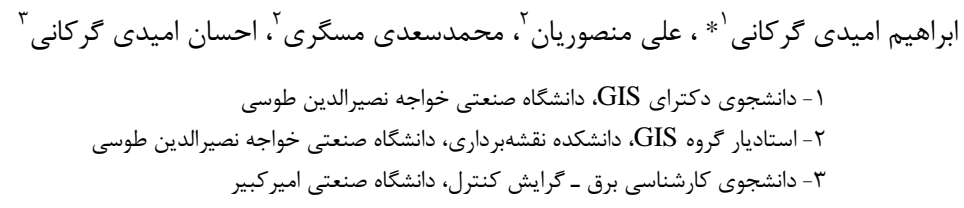

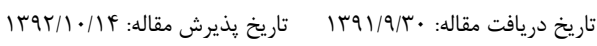

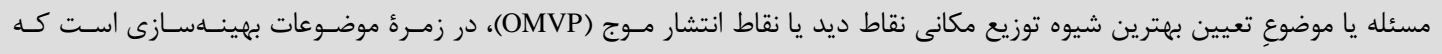

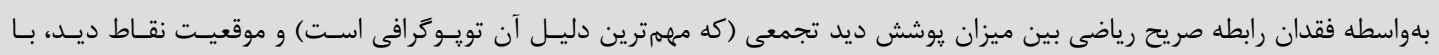

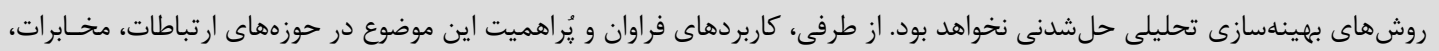

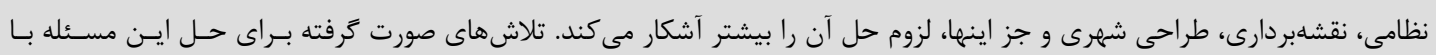

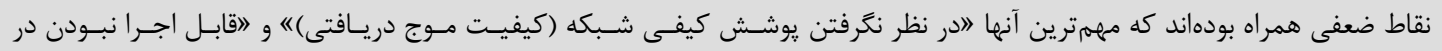

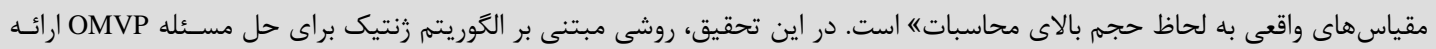

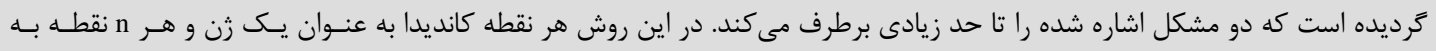

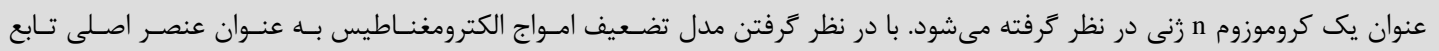

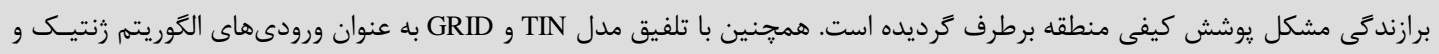

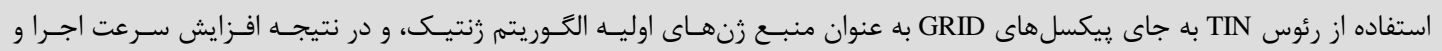

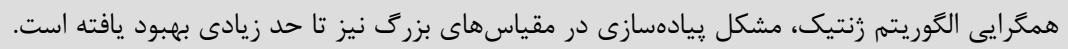
كليدوازهها: ميدان ديد، مدل انتشار موج، توزيع بهينه منابع انتشار، تضعيف امواج، الكوريتم زنتيك، بهينهسازى، TIN.

* نويسنده مكاتبه كننده: تهران، خيابان وليعصر، تقاطع ميرداماد، دانشكاه صنعتى خواجه نصيرالدين طوسى، دانشكده نقشهبردارى. تلفن: VV9.VIII Email: ebrahim.omidi@gmail.com 
نقشهبردارى و دوربينهاى ليزراسكن و نظـاير اينهـا در

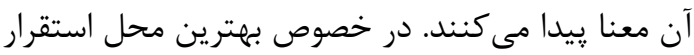

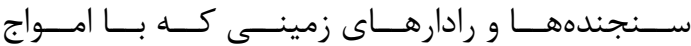

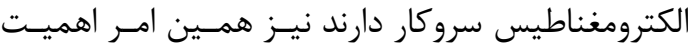

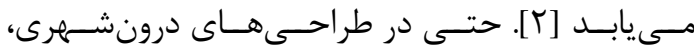
كاربرى هـاى امنيتـى و تعيـين بهتـــين مكـان اسـتقرار

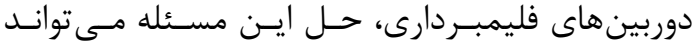
راهكشا باشد. نكته درخور توجه اينجاست كه حـل ايـن ائن

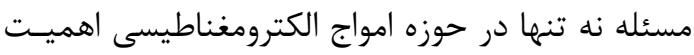
دارد بلكه در مورد يديدههايى هم كه تا حـدودى رفتـار مشابه امواج دارند (رفتارى نظير خـط سـير مسـتقيم)،

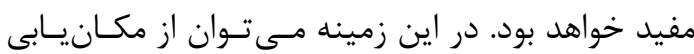
استقرار توربينهاى بادى نام برد كه به واسطه شـباهت نسبى يديده باد با امواج، به حداكثر رساندن ميدان ديد

توربين بادى ارزشمند خوهد بود [س].

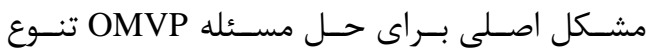

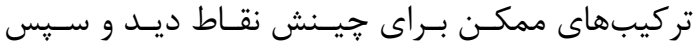

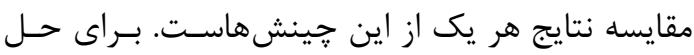

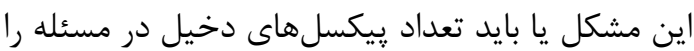

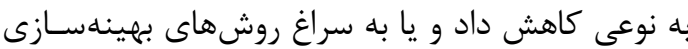
تصادفى ' رفت كاهن براى كاهش تعداد نقاط دخيل در مسئله، تحقيقاتى

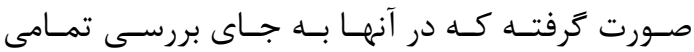
تركيبهاى ممكن پِيكسلها، تنها يیكسلهاى با شرايط

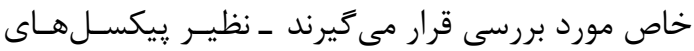

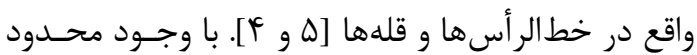
كردن نقاط جستوجو در اين تحقيقات، در صورتى كـهـ

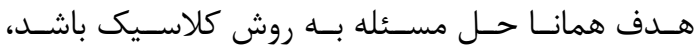
همجنان روند حل مسئله بسيار زمانبر و عملاً نـاممكن هماتِ

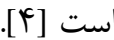

تلاشها و تحقيقاتى نيز بهمنظور اتخـاذ روشهـيى به غير از روش كلاسيك صورت كرفته است. در اين نوع

1. Optimal Multiple Viewpoint

2. stochastic
- 1 - - 1قدمه

با قدرتمند شدن توابع تحليل مكانى GIS از يك سـو و كسترش روزافزون استفاده از فناورى ارتباطات و به تبع آن امواج الكترومغناطيس از سوى ديخر، مسائل ييرامون يوشش اين امواج نيز اهميت بيشترى يافته است. امواج الكترومغناطيس طيف وسيعى از طول موجهـا را شـامل مىشوند كه نور مرئى، امواج راديويى، امواج مخـابراتى و إنى

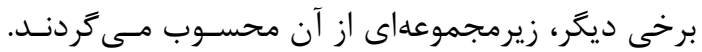

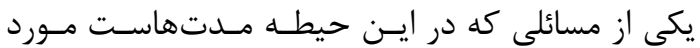

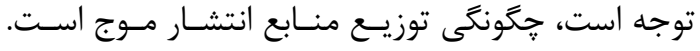

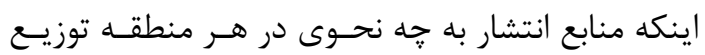
شوند كه بهترين يوشش را در آن منطقه ايجـاد كنـــد،

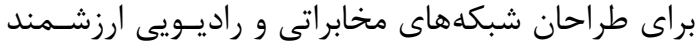

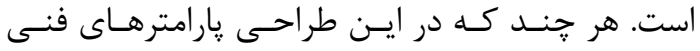

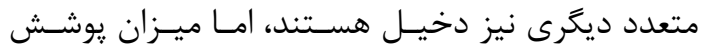

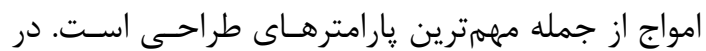

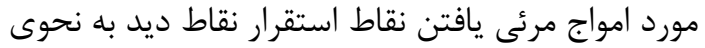

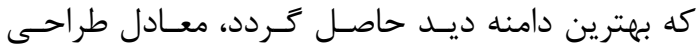
منابع انتشار موج است. از ديدكاه كاربردى و در عمل نيز مسئله ميدان ديد التحا

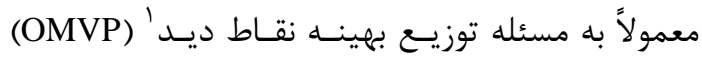

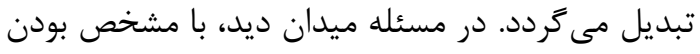

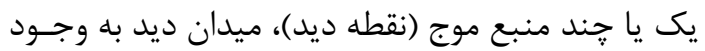

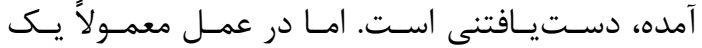

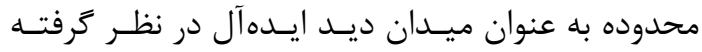
مى شود و استقرار نقاط ديد به نحوى صورت مسى دئيـرد

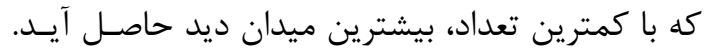
اين موضوع به شدت در مكانيابى ايستخاههاى راديويى

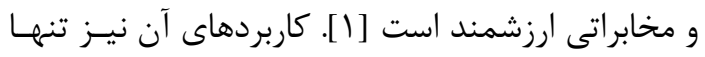

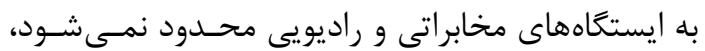
بلكه در محدوده طيف رنتىى، كاربردهـايى نظيـر محـل

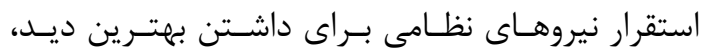
تعريف نقاط كردشكرى، بهترين مسير عبور جاده (براى نئرئ

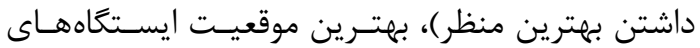


ارسالى نيز اهميت دارد و در خروجى تأثير كذار خواهـــ بود. همجنين با تلفيق مـدل TIN و GRID بــ مئه ميـزان زيادى از حجـم محاسـباتى و مشـكلاتى كـهـ تحقيقـات

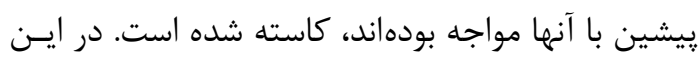
تحقيق تمركز اصلى بر روى امواج مخابراتى است، كه از كاربردى تـرين طيـفـهـاى الكترومغنــاطيس بــه شـمار

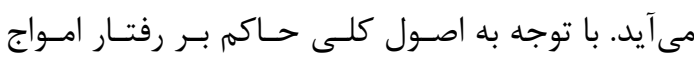

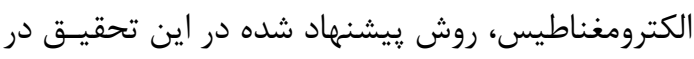

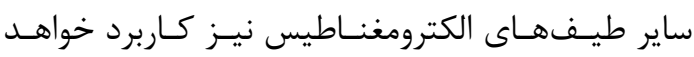

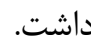

در بخش ا اين تحقيق، به پـيشنيازهـا و ابزارهـاى نظرى مورد نيـاز بـراى حـل مســـله OMVP يرداختـهـ

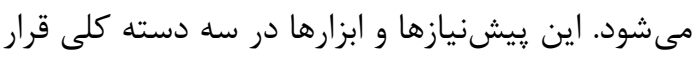

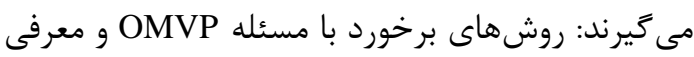

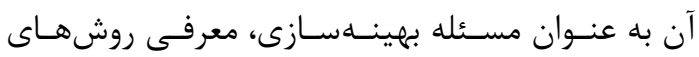
بهينهسازى و به طور خاص مبـانى و مزايـاى الكَـوريته

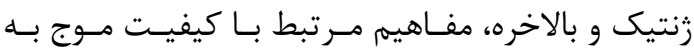

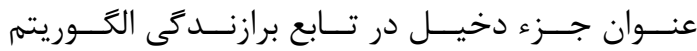
بهينهسازى اين تحقيـق. در بخـش ب ايسن تحقيـق، بــا تلفيق اصول مذكور، سعى در تعريف سـاختار الخــوريته دئه

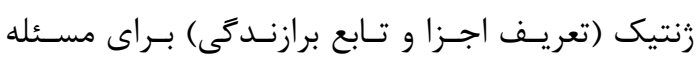

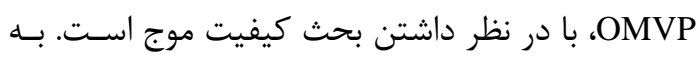
علاوه، نحوه تلفيق TIN و Grid براى كاهش محاسـبات

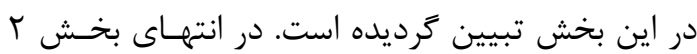

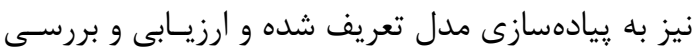

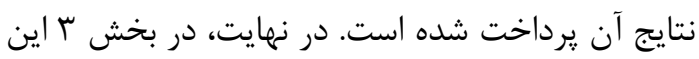

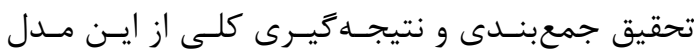

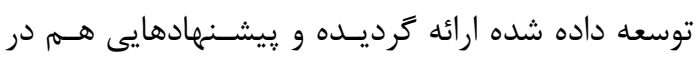
ادامه تحقيقات از اين نوع مطرح شده است.

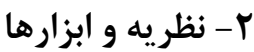

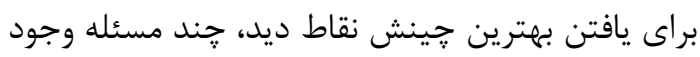

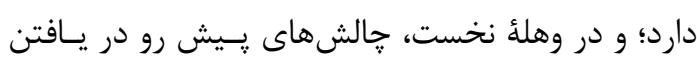

تحقيقات، مسئله به صورت مسئله بهينهسـازى در نظـــ

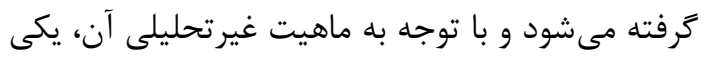
از روشهاى بهينهسازى تصادفى به كار كرفته مى شـودي.

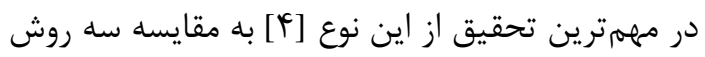
بهينهسازى Swap Algorithm و Simulated Annealing براى حل آن يرداخته شده است. امتياز اين

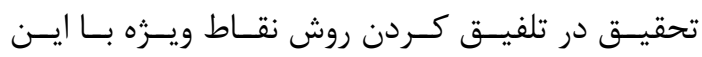
روشهاى بهينهسازى است كه باعث افزايش كار ايى آنها كرديده است. اما دو مشكل اساسى اين تحقيق همجنان بالا بودن حجم محاسـبات بـراى GRIDهـاى حجـيمى و ديخرى در نظر ترفته نشدن كيفيت موج دريافتى است.

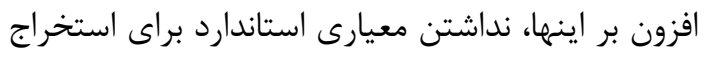

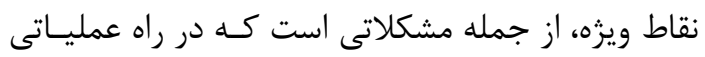
بودن اين تحقيق به جشم مى خورد.

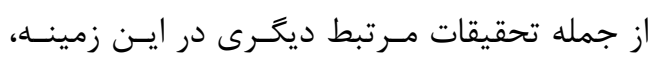

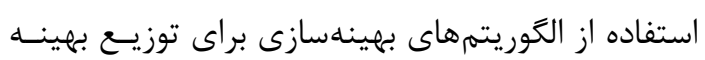

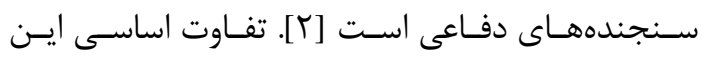

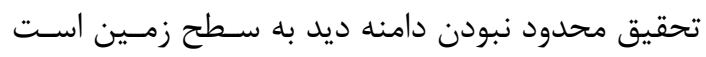

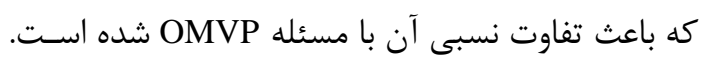

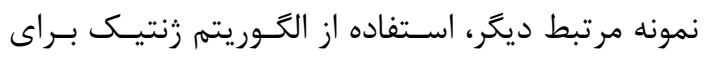

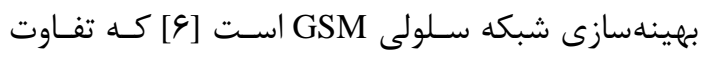

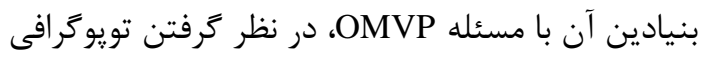

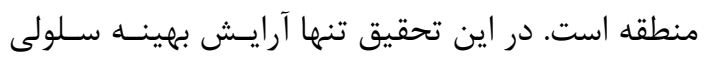
شبكههاى GSM از نظر هندسى مورد توجه قرار كرفته

بايسـد توجــه داشـت كــه نحــوه يوشـش امـواج

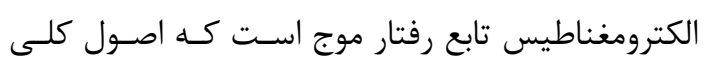

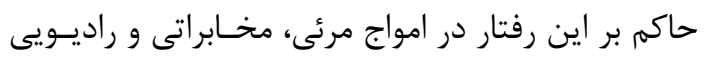

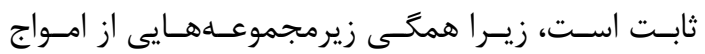
الكترومغناطيس محسوب مى گردند [V]]. در اين تحقيق

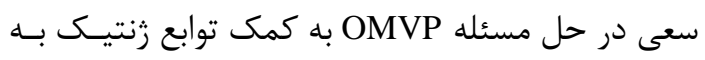

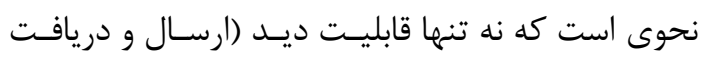

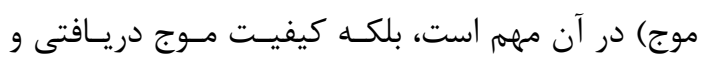


از مرتبه O(n2) وجود دارد كه به هر حـال حـلـشـنى است [F]؛؛ اما وقتى هدف يافتن بهتــرين محــل اسـتقرار براى V منبع موج باشد، به نحوى كه مجموعه يوشـش

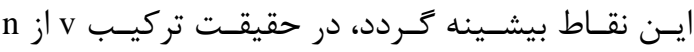
ييكسل برابـر بـ صورتى كه n>> محاسبه اين تركيب تقريباً مرتبـهاى

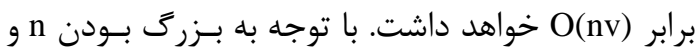

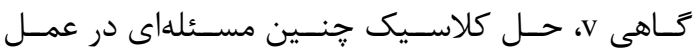
امكانيذير نيست و بايد به دنبال روشهاى ديگرى براى

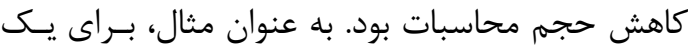
GRID

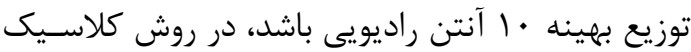

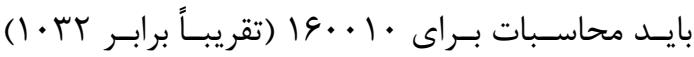
حالت ميدان ديد محاسبه شود و بهترين حالت انتخـاب كردد.

اين روش گر جــه دقيـقتـرين نتيجــه را بــه دسـت

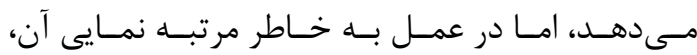

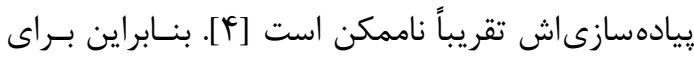

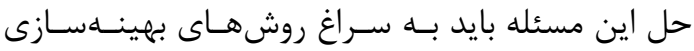
آتاهانه' رفت.

r-r- مسائل بهينهسازى و الكَوريتم زنتيك

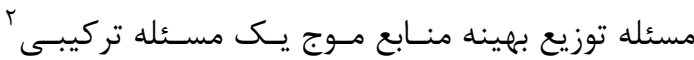

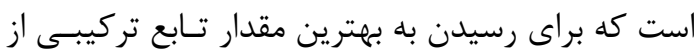
روش هاى بهينهسازى استفاده مى شود. بنابراين مسـئله

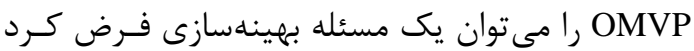

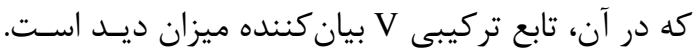

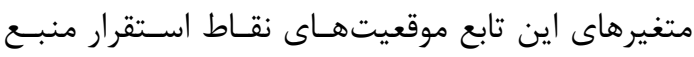

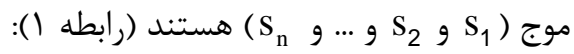
$V=f\left(s_{1}, s_{2}, \ldots, s_{n}\right)$
(1) رابطه (1)

1. heuristic

2. combinatorial
بهترين جينش. با توجه به اينكه اين مسـئله بـهـ نـوعى

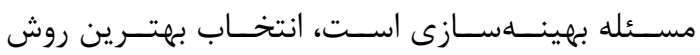
بهينهسازى براى آن اهميـت ويـزرهاى دارد. از آنجــا كـهـ يكى از اهداف اين تحقيق در نظر گرفتن كيفيـت مـوج دريافتى در فرايند تصميهم گيسرى اسـت، انتخــاب مـدل

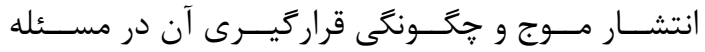
بهينهسازى نيز اهميت مىيابـد. بنـابراين قبـل از ارائـهـ

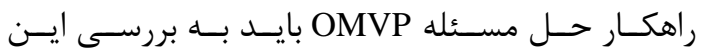
موضوعات ״رداخت.

\section{YMVP T-1- مسئله}

تجزيه و تحليل مدل سهبعدى منطقه به منظور تعيـين

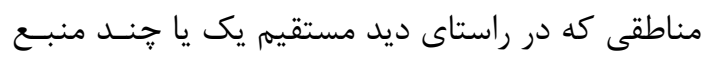
موج (منبع نور) قرار مى گيرند، به توليـد نقشـهـ ميـدان ديد منجر مىشود. در حقيقت ميدان ديـد را مسى مـوان

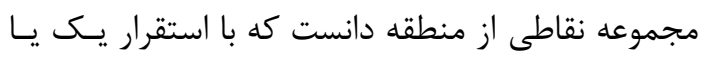

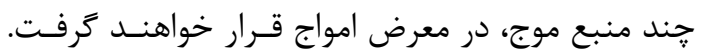

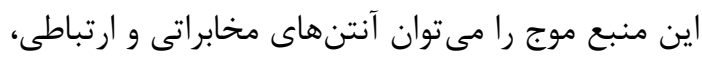

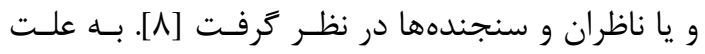

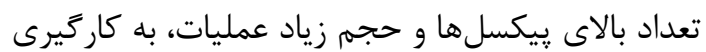
الخوريتم يايه (استفاده از خط ديد) براى تعيين ميـدان

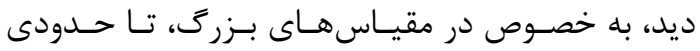

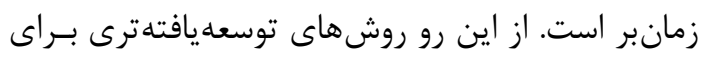
كاستن از اين مشكل ارائه شدهاند [9].

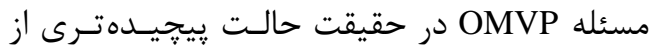
مسـئله ميـدان ديـد اسـت. هـدف آن، يـافتن بهتــرين جينش نقاط ديد (منابع انتشار موج) اسـت، تـا بهتـرين ميدان ديد به دست آيد. بهترين ميدان ديد تنها معادل بيشترين ميدان ديد نيست، بلكه همان گونه كه در ايـن تحقيق مدنظر است، كيفيت يوشـش نيـز مسىتوانـد در تعيين بهترين جينش اهميت فراوان داشته باشد. حل مسئله OMVP زمانى با مشكل مواجه مىشـود

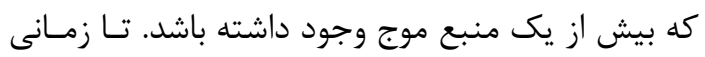
كه هدف تنهها يافتن يك نقطه به عنوان نقطـه اسـتقرار

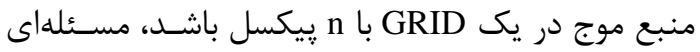


در روشهــاى عـددى قطعـى، مقـــدار دهــى بـــه

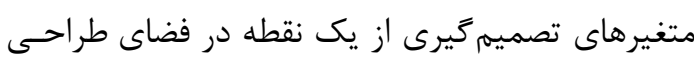
شروع مىشود و سيس مقادير جديـــ ايـن متغيرهـا در

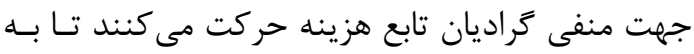

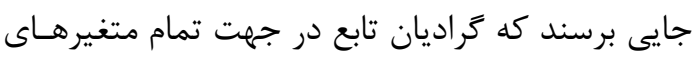

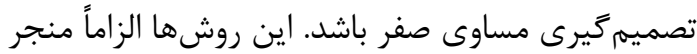
به يافتن بهينه كلى نخواهند شد. در مواردى كه مسائل ييجيدهاى وجود دارند كـه در

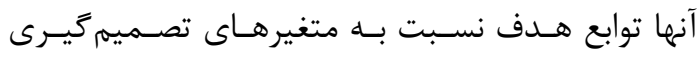

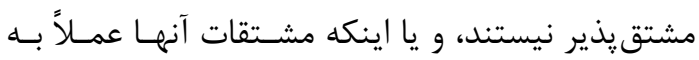

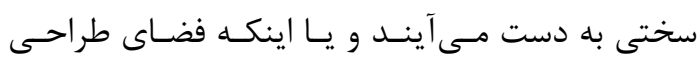

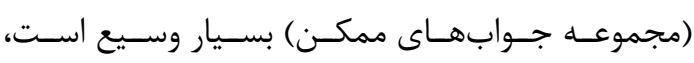
روشهاى عددى قطعى با ضعف مواجه خواهند شـد. در

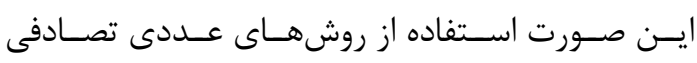

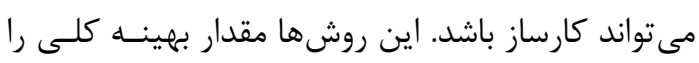

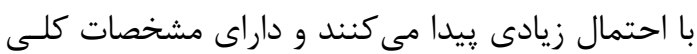

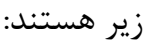

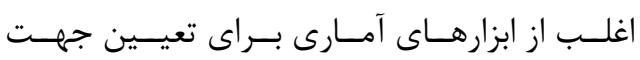
جستوجو استفاده مى كنند؛

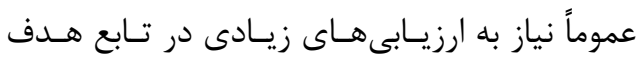

$$
\text { دارند؛ و }
$$

معمولاً وابسته به مشتق گيرى تابع هدف نيستند.

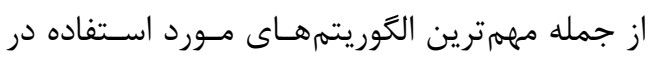
روش هاى عددى تصادفى، مى توان به اين مـوارد اشـاره كرد: Simulated Annealing كرم و سرد كردن مواد بـراى توليـد بهتـرين ابعـاد

$$
\text { كريستالى است [1] [11]. }
$$
Ant Colony يافتن بهترين مسير در يك گراف است [1 [1]]. الگوريتم زنتيك: كه با الگوگيرى از تئورى تكامل و

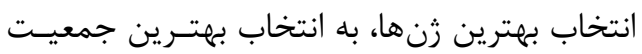

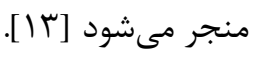

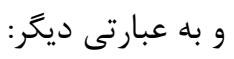

$\mathrm{V}=v \mathrm{~S}_{1} \cup v \mathrm{~S}_{2} \ldots \cup \mathrm{vS}_{\mathrm{n}} \quad$ (T)

در رابطه (Y)، U نشاندهنده اجتماع ميـدانهـاى

ديد و vS نشان دهنده ميدان ديد براى نقطـه (منبـع

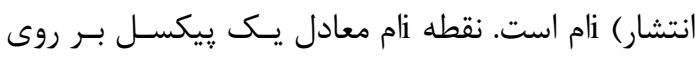
GRID

براى بهينهسازى جنين تابع تركيبـى بايسد بهتـرين

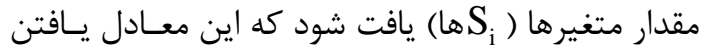
بهترين نقاط استقرار منابع موج است. بنابراين بايد يكى مئى مافي از روشهاى بهينهسازى براى حل مسئله انتخاب شود.

\section{r-r-1- - روش هاى بهينهسازى}

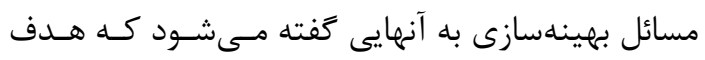
تعيين متغيرهاى يك تابع هزينه (يـا تـابع تناسـب) در آنها به گونهاى است كه مقدار تابع هزينه كمينـه (و يـا مقدار تابع تناسب بيشينه) گَـردد. دو روش كلـى بـراى حل مسائل بهينهسازى عبارتاند از روش هاى تحليلى و روشهاى عددى [ • [1].

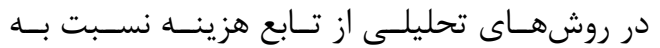

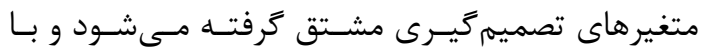

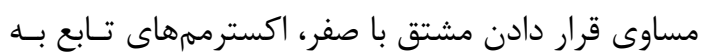
دست مى آيند. اين روش در مواردى به كار مـىرود كـهـ

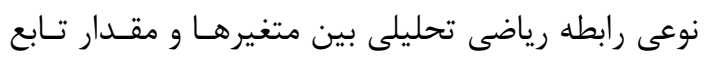

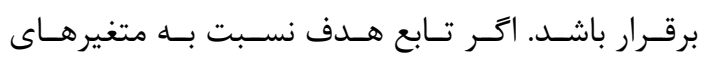

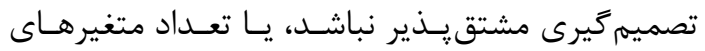

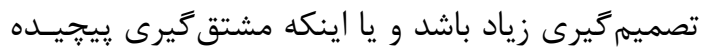
باشد، روشهاى تحليلى كارايى نخواهند داشت.

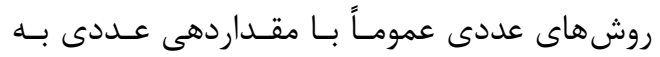
متغيرهاى تصميمَيرى و سيس ارزيابى در تابع هدف و

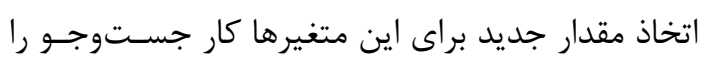

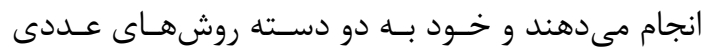
قطعى ' و روش هاى عددى تصـادفى تقسـيمم مـى دهـوند .[1·] 


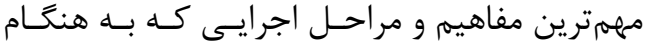

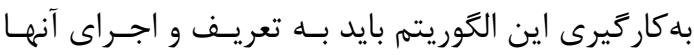

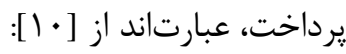

فرد يا كروموزوم (Chromosome)

جمعيت (Population)

كدگذارى (Encoding)

تابع برازندگى (Fitness)

انتخاب (Selection)

تقاطع (Crossover)

جهش (Mutation)

نخبه
• كه در دسته الخوريتمهاى هوش گروهى قرار :PSO

مى كيرد و هدف آن هدايت ذرات داخل يك گَروه،

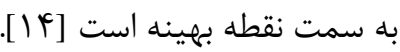

با توجه به ويزگى هاى مسئله OMVP و به خصوص به بنه

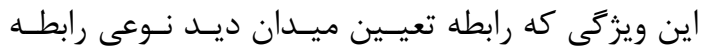
تحليلى رياضى نيست و مشتق كيــرى از ايسن رابطـهـ بــهـ

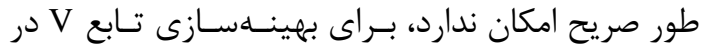

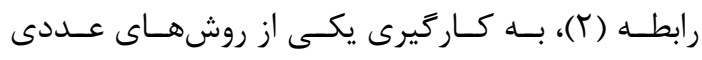
تصادفى، مورد نياز است.

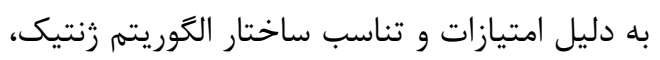
در اين تحقيق از روش رزنتيك براى اين منظور اسـتفاده

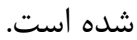

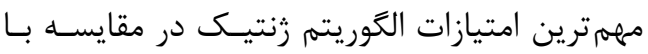
ديخر روشهاى بهينهسازى عبارتاند از [ • []:

الكوريتم زنتيك، به طور همزمان روى مجموعـهاى

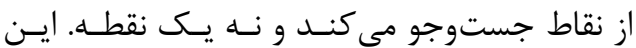
ويزگ بهى به خصـوص در مـورد مسـئله OMVP كـهـ حجم زياد جستوجو وجود دارد، سودمند است.

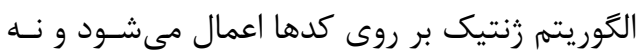

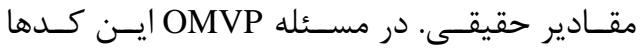
مىتوانند متناظر با شناسه نقاط كانديدا باشند.

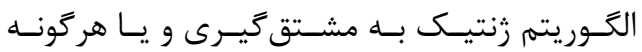

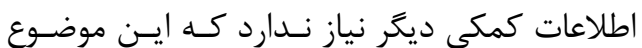
خود در مسئله OMVP بسيار ارزشمند است. در طول ايجاد نسل هاى متوالى، هـيجَــاه بهتـرين

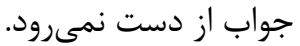

ايـن امتيـازات و اهميـت آنهـا در مسـئله OMVP،

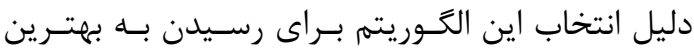

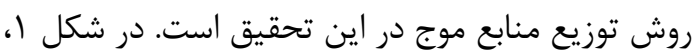

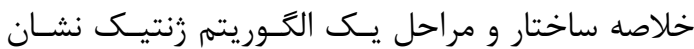

r-r-r-r- الكوريتهم زنتيك و امتيازات آن

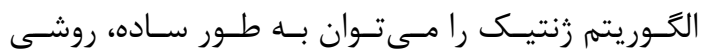

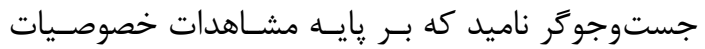
فرزندان نسلهاى متـوالى و انتخـاب فرزنـــان براسـاس

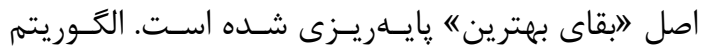
زرنتيك بر روى فرزندان يكى نسل، از قـوانين موجـود در علم زنتيك تقليد مى كند و با به كار بردن آنها، به توليـد

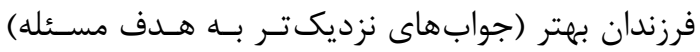

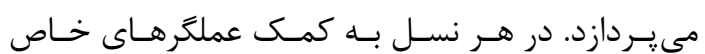

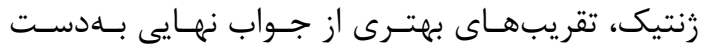

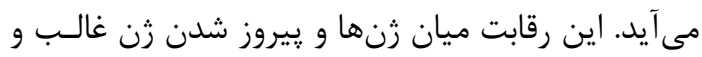

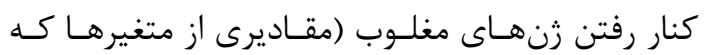

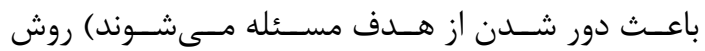
كارآمدى براى حل مسائل بيجيجيـده و دشـوار بــهـ شـمار

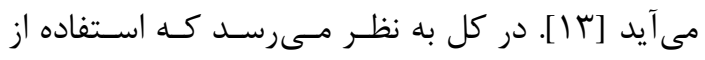

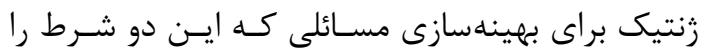
داشته باشند، كارساز خواهد بود:

فقدان رابطه صريح تحليلى بـين ميـزان تناسـب و متغيرهاى تصميم خيرى؛ و وانيخ جواب تركيبى حاصل از جند متغير. 


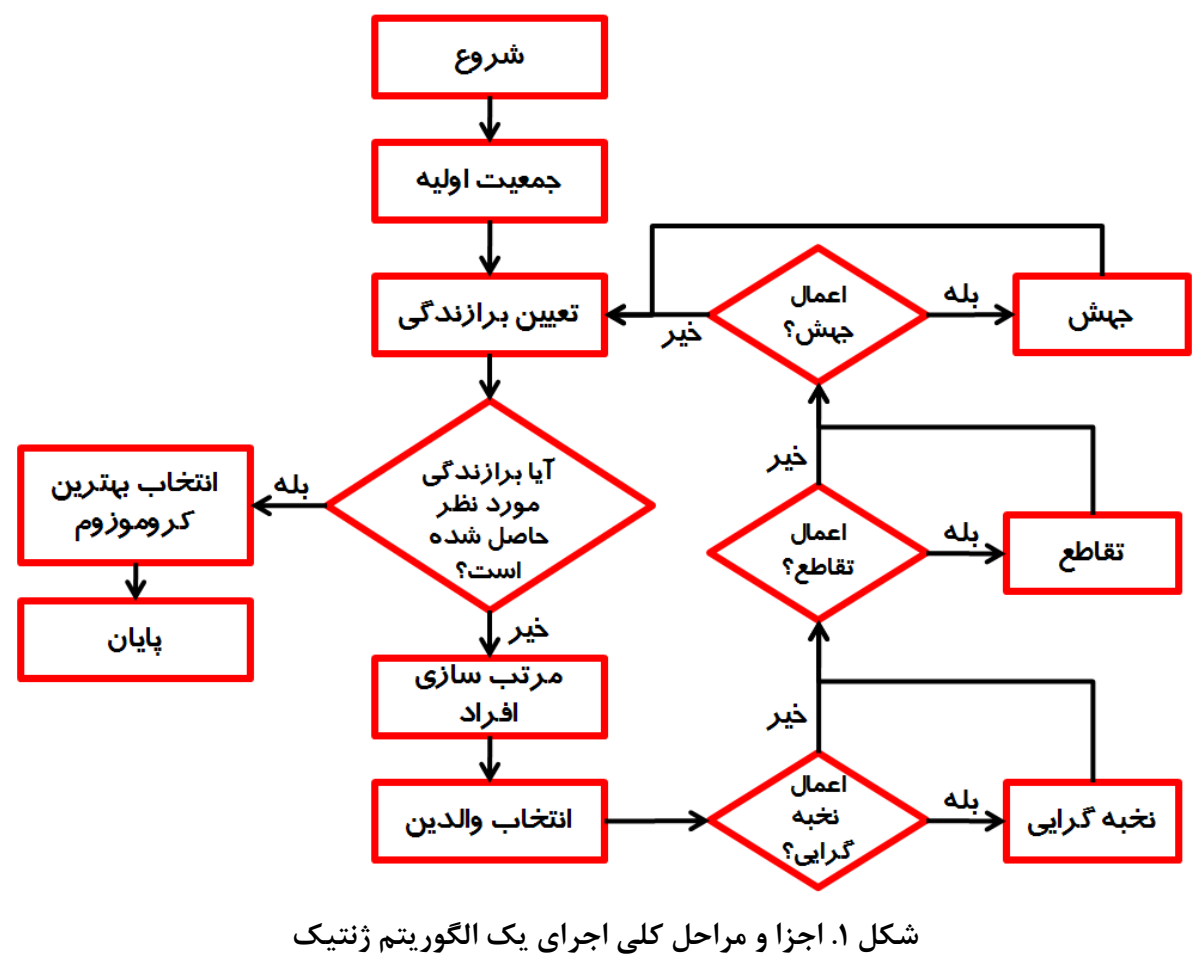

متعددى دارد كه يكى از مهمتـرين آنهـا مسـير ارسـال موج است و به اين بخش، تضعيف مسـير (Path Loss)

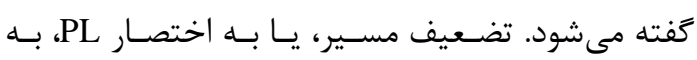
معناى كاهش انـرزى مــوج الكترومغنــاطيس در هنَّـام

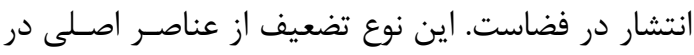

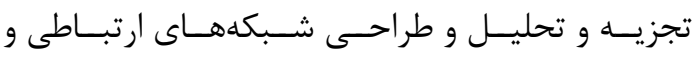

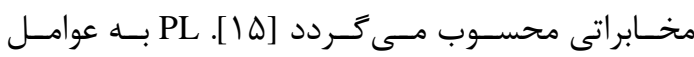

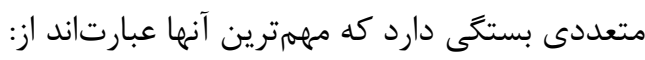

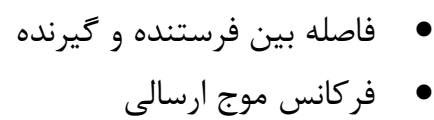
• نوع محيط انتشار (شهرى، روستايى، جنكلى و جـز اينها) جنس محيط انتشار (هواى خشك يا مرطوب)

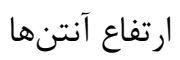

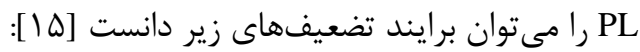
تضعيف ناشى از انتشـار (Propagation Loss) كـه

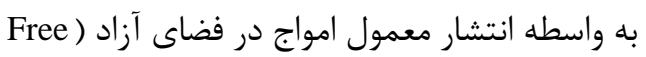
(Space r-r- r- مسئله كيفيت موج

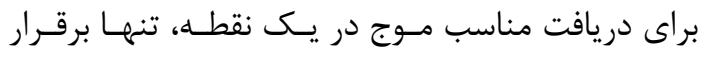

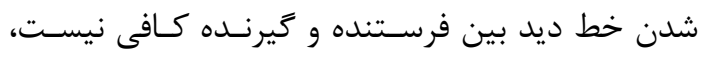

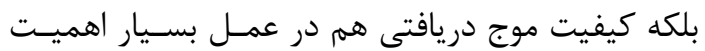
دارد. در آناليزهاى ميدان ديـد كـه تـاكنون در محسيط

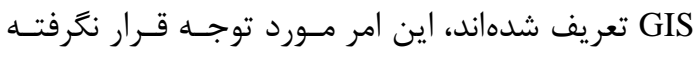

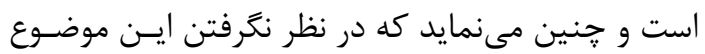

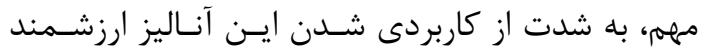
جلوكيرى مى كند. براى حل اين مشكل در اين تحقيق،

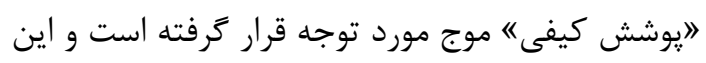
به معناى در نظر كـرفتن نحـوه رفتـار مـوج در محسيط

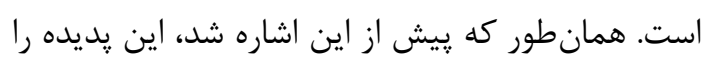

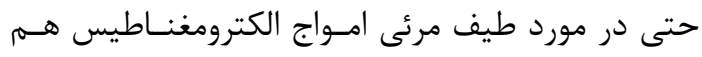

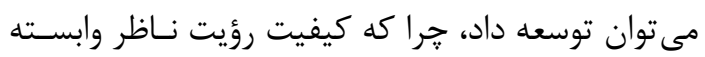
به فاصله نقطه از ناظر خواهد بود. در حوزه امـواج، بديـدهاى بـهـ نـام تضـعيف (Loss)

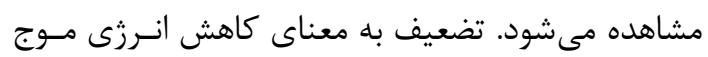
دريافتى نسبت به موج ارسالى است. اين تضعيف عوامل 
است، به † و در محيطهاى نسبتاً برافت به أ مىرسـد. اين محيطها مى توانند به واسطه ذرات آب، گرده و غبــار

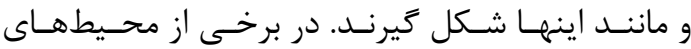

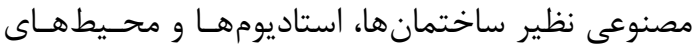
بسته اين مقدار به 9 نيز مى رســد و در عـوض برخسى از

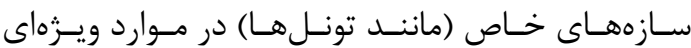

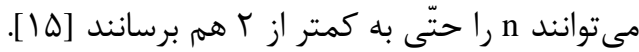

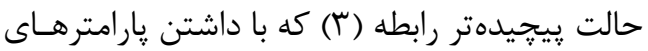

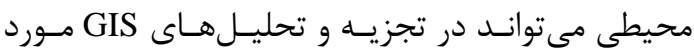

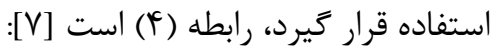

PL $=L_{\circ}+10 / \log _{10} \frac{d}{d_{\circ}}+X_{g}$ (f) (f)

كه در آن d فاصله مبنا و L ميزان PL در طول

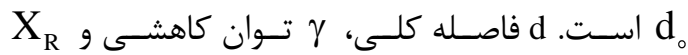
بخشى از تضعيف است كه بهواسـطه يديـده Fading در

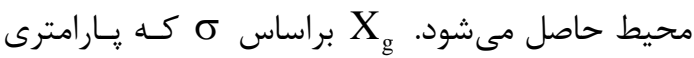
وابسته به محيط است، قابل محاسبه است. در جدول ال، ل،

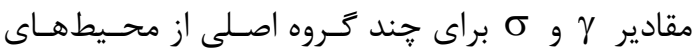
انتشار، نشان داده شده است:
تضعيف ناشى از جذب (Absorption Loss) كه در هنگام عبور سيخنال از موانع ظاهر مى گردد؛

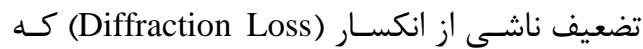
وقتى بخشى از جبهه موج بــه موانـع برمسى خــورد،

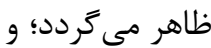
ساير تضعيفها.

براى محاسبه ميزان كاهش كيفيت موج، بايد تمـام يارامترها و عوامل ذكر شده، در محاسبه وارد گردند. اما دخالت دادن همه اين يارامترها بـهـ طـور همزمــان كـار

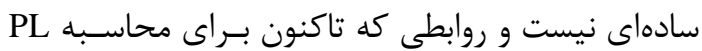
شكل گرفتهاند، بر اساس مهــمتـرين عوامـل تأثيرگـــار هستند. در سادهترين قالب نمـايش، PL را مسى تـوان از رابطه (س) بهدست آورد:

PL $=10 \log _{10}(d)+c \quad$ (r)

در رابطه (ז)، PL بيان كننده ميزان كـاهش انـرزى موج، d فاصله بين فرستنده و گيرنده، n توان كاهشى و c مقدارى ثابت به ازاى هر فركانس است. توان كاهشىى

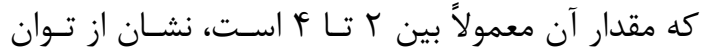
تضعيف موج در محيط ارسالى دارد. اين توان در فضاى

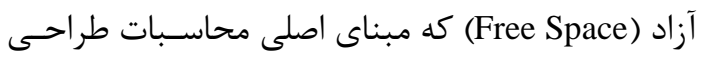

جدول ا. مقادير تجربى $\gamma$ و م براساس محيط انتشار و فركانس

\begin{tabular}{|l|l|l|l|}
\hline \multicolumn{1}{|c|}{ Building Type } & Frequency of Transmission & $\gamma$ & $\boldsymbol{\sigma}$ [dB] \\
\hline Vacuum, infinite space & & 2.0 & 0 \\
\hline Retail store & $914 \mathrm{MHz}$ & 2.2 & 8.7 \\
\hline Grocery store & $914 \mathrm{MHz}$ & 1.8 & 5.2 \\
\hline Office with hard partition & $1.5 \mathrm{GHz}$ & 3.0 & 7 \\
\hline Office with soft partition & $900 \mathrm{MHz}$ & 2.4 & 9.6 \\
\hline Office with soft partition & $1.9 \mathrm{GHz}$ & 2.6 & 14.1 \\
\hline Textile or chemical & $1.3 \mathrm{GHz}$ & 2.0 & 3.0 \\
\hline Textile or chemical & $4 \mathrm{GHz}$ & 2.1 & $7.0,9.7$ \\
\hline Metalworking & $1.3 \mathrm{GHz}$ & 1.6 & 5.8 \\
\hline Metalworking & $1.3 \mathrm{GHz}$ & 3.3 & 6.8 \\
\hline
\end{tabular}


موج الكترومغناطيسى است و بنابر اين ديمانسيون آن از

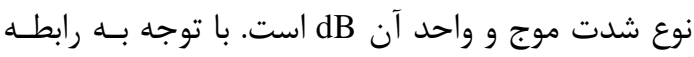

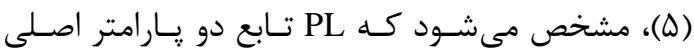

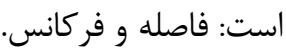

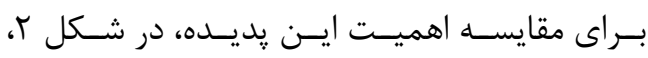

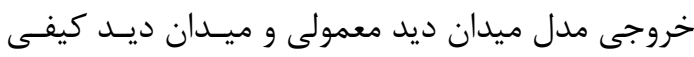

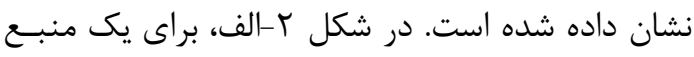

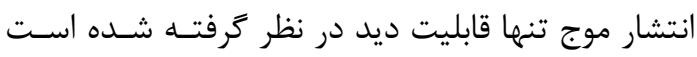

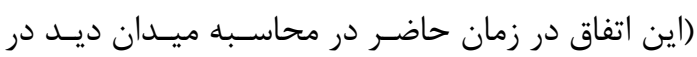

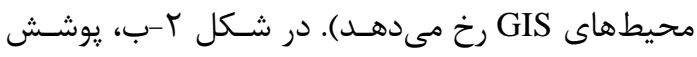
كيفى همان منطقه بلهوسيله همان منبـع انتشـار نشـان داده شده است.
در زمــان حاضـر بــراى طراحسى و محاسـبات فنسى

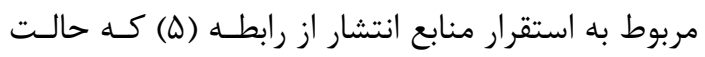

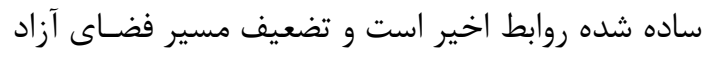
(Free Space Path Loss)

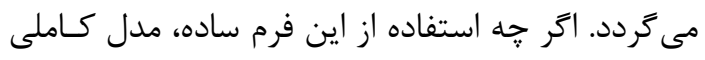

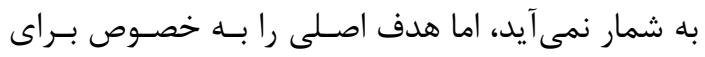

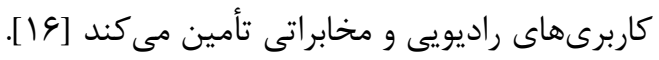

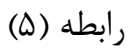

$P l=32 / 5+20 \log _{10} d+20 \log _{10} f$

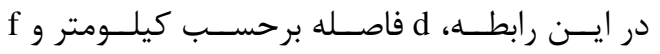

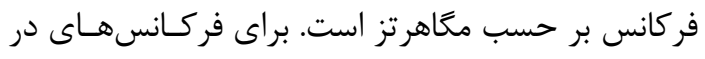

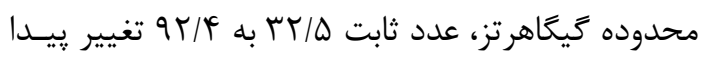

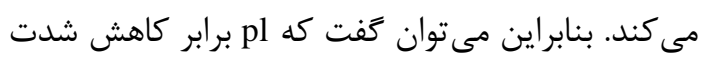

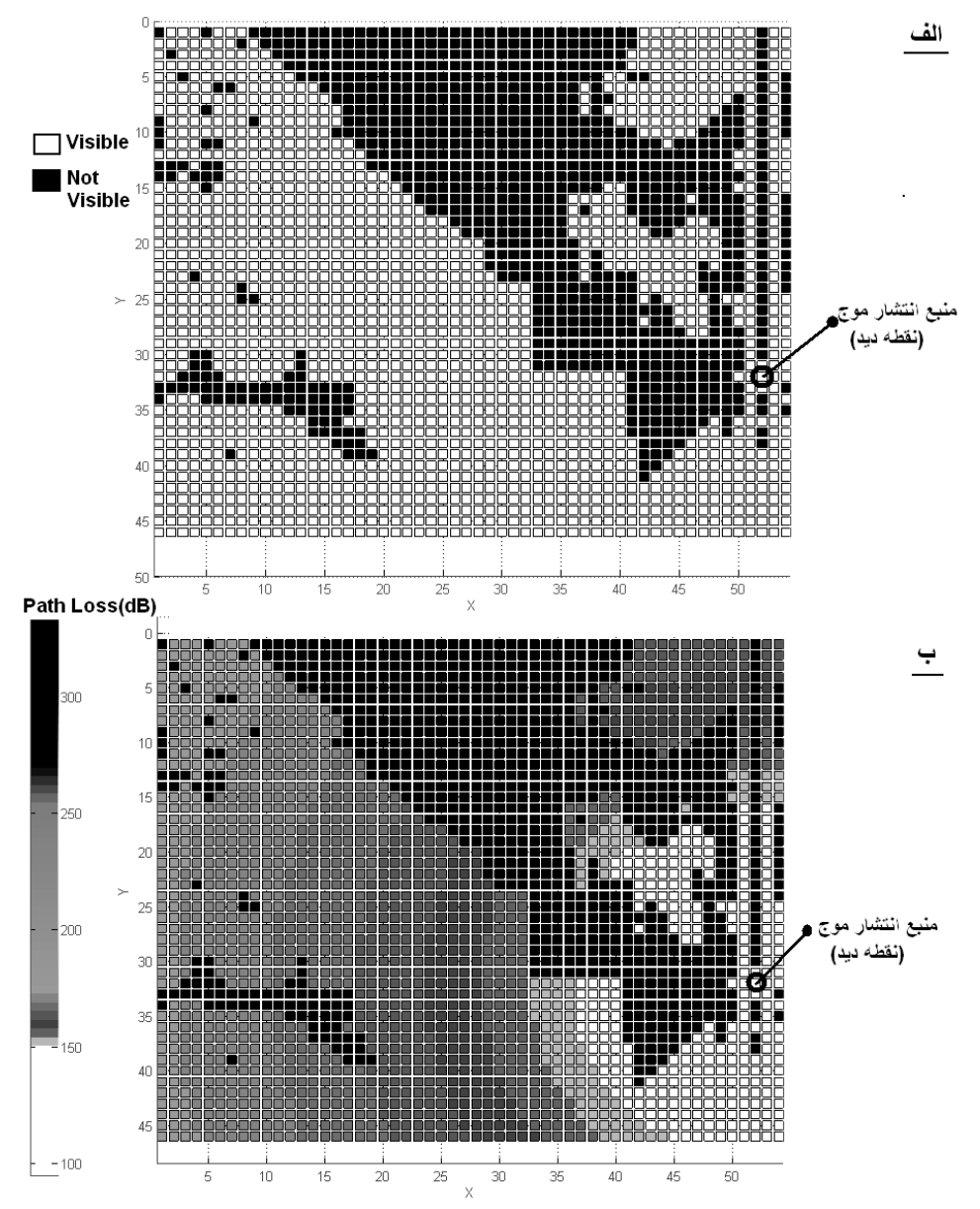

شكل r. الف) ميدان ديد يك منبع انتشار موج؛ و ب) ميدان كيفيت ميدان ديد همان منبع 


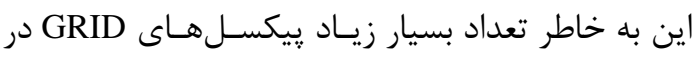

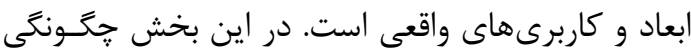
حل اين مسائل در اين تحقيق بررسى مى

ץ-1- تعريف اجزاى الكَوريتم زنتيك براى مسئله

OMVP

با توجه به خواصى كه براى الكَوريتم زنتيك ذكر شـد و

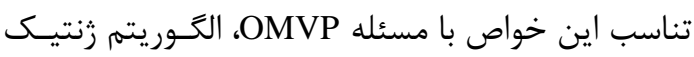
براى حل اين مسئله مناسب ارزيابى مى كردد. بنـابراين بايد اجزاى اصلى الكوريتم زنتيك را در اين قالب مسئله OMVP

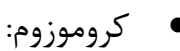

هـر كرومـوزوم معــادل يـك جــواب مســئله اسـت.

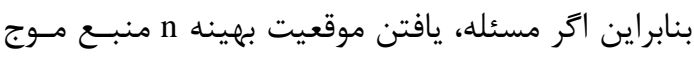

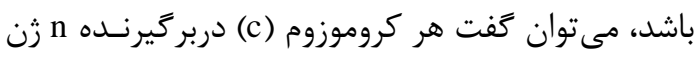

$$
\text { رابطه (ع) }
$$

كه در آن آنوا دربر كيرنده زنها

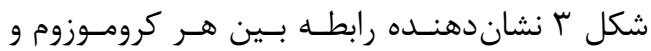
زنهاى مرتبط در مسئله OMVP است. در ايـن شـكل

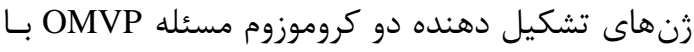

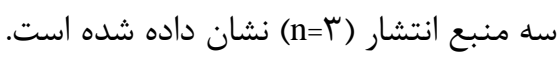

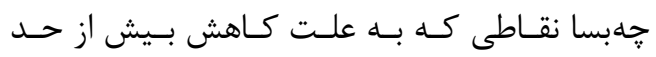

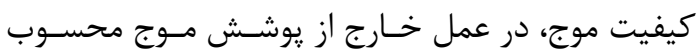

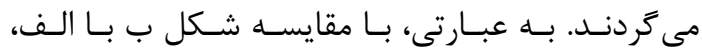

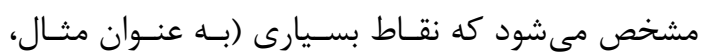

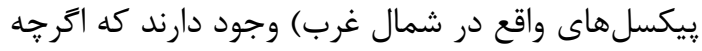

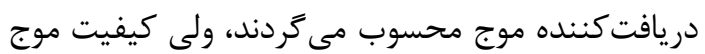

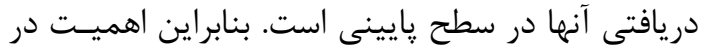
نظر كرفتن يوشش كيفى در مكـانيـابى منـابع انتشـار

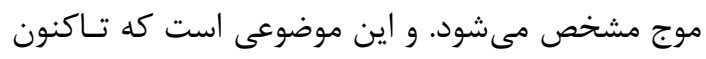

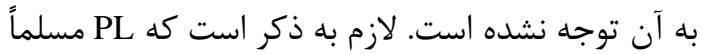
فقط براى بيكسل هايى محاسبه مى شود كه در محدوده

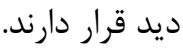

\section{r- تعريف و קييادهسازى مدل} همانطور كه يِيش از اين كَفته شد، حل مسـئله توزيـع

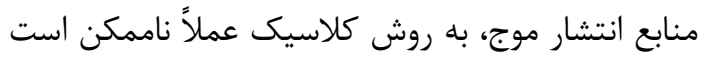

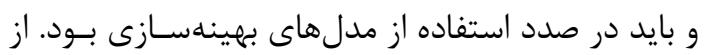

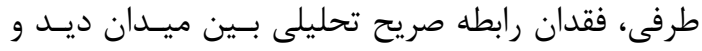

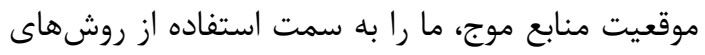
بهينهسازى عددى تصادفى سوق مى دهد. در استفاده از

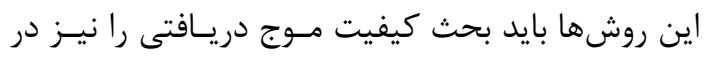

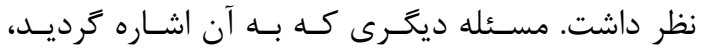

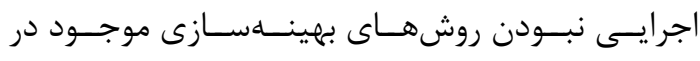
مقياسهاى بزرى و در پِيادهسازىهاى واقعى است، كـهـ

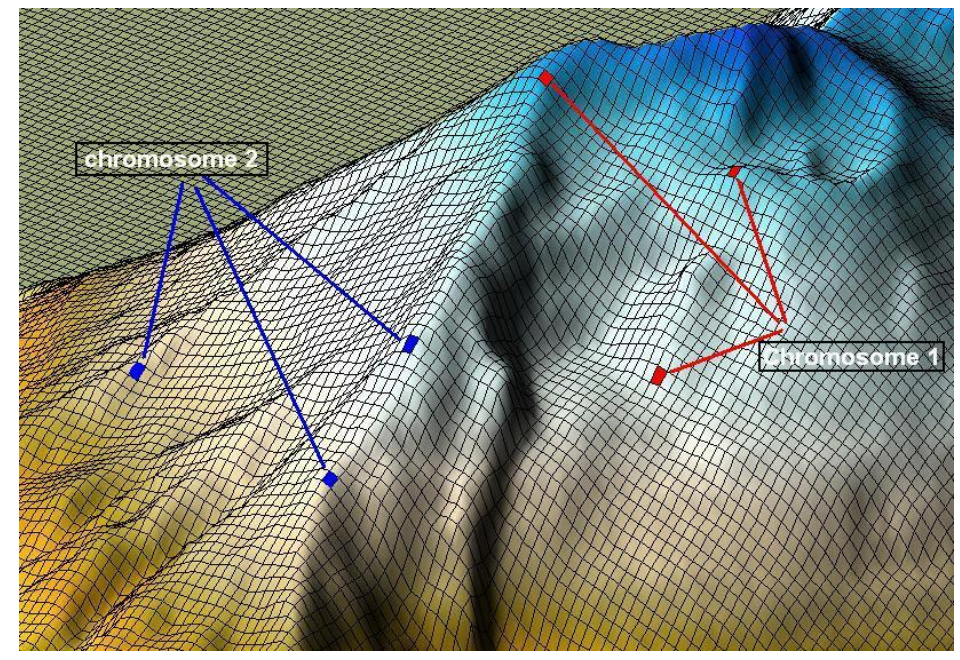

شكل r. تشكيل دو كروموزوم نمونه براى مسئله OMVP با سه منبع انتشار 
داشته باشد، بهترين كيفيت دريـافتى (كمتـرين ميـزان PL

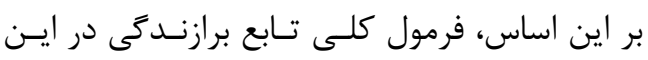
تحقيق معادل رابطه (V) در نظر كرفته شده است:

رابطه (V)

$F(c)=\frac{\sum_{i=1}^{m} \operatorname{PL}(i)}{m \times \operatorname{PL}(\max )}$
$\operatorname{PL}(i)=\operatorname{Min}\left\{\operatorname{PL}\left(i, g_{1}\right), \operatorname{PL}\left(i, g_{2}\right), \ldots, \operatorname{PL}\left(i, g_{n}\right)\right\}$ كه در اين رابطه:

c ميزان تناسب (تابع برازندگى) براى كروموزوم: F(c)

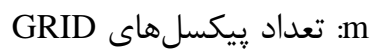
ميزان تضعيف موج دريافتى در يِيكسل ili) PL(i) بكار PL(max) رِيكسل هايى كه در معرض ديد قرار ندارند، ايـن مقـدار

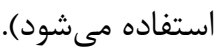

SمL(i,gi)

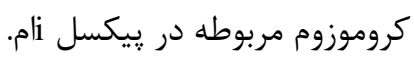
كمينه شدن تابع F(c) به معناى رسيدن به به به بهترين

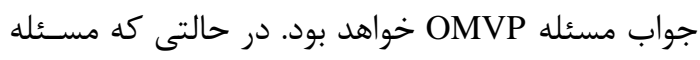

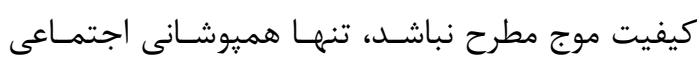

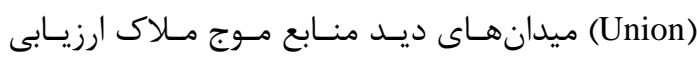

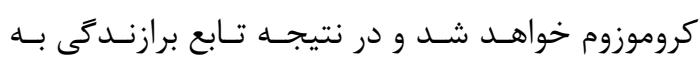
صورت سادهتر رابطه (^) تبديل مىشود:

رابطه (ᄉ)

$\mathrm{F}(\mathrm{c})=\frac{1}{\operatorname{Union}\left(\mathrm{vs}\left(\mathrm{g}_{1}\right), \mathrm{vs}\left(\mathrm{g}_{2}\right), \ldots, \mathrm{vs}\left(\mathrm{g}_{\mathrm{n}}\right)\right)}$

كه در آن vs(gi)، برابر محدوده ميدان ديد براى زن

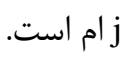

اما يكى از اهداف اصلى اين تحقيق، در نظر خـرفتن يوشش كيفى ميدان ديد است. اين بدان معنى است كه إنه

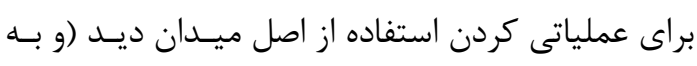

در مسئله OMVP جمعيت (p) برابر خواهد بود بـا:

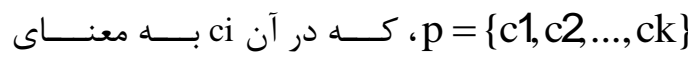

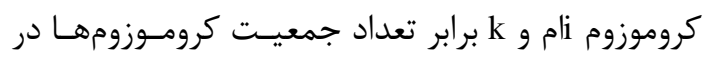

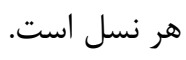

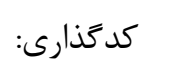

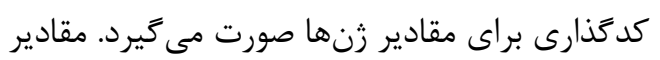

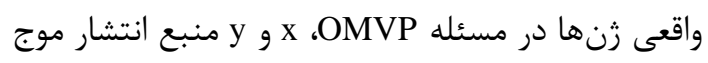

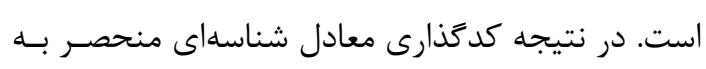

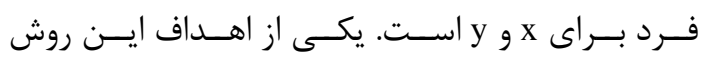

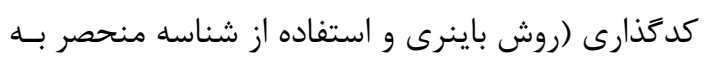

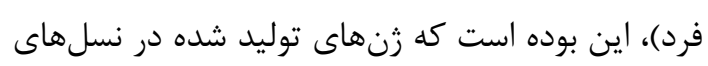

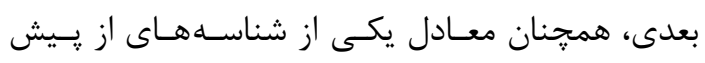

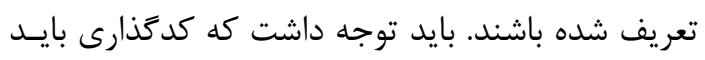

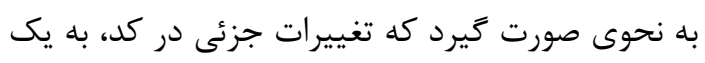
تغيير جزئى در X و y بينجامد.

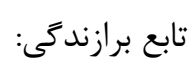

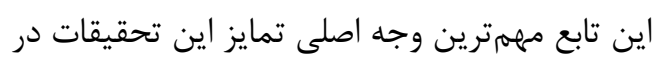

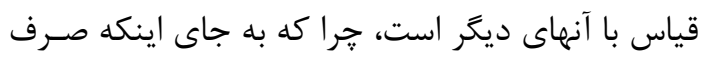

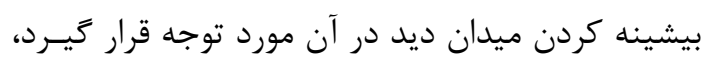

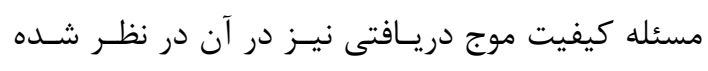

با توجه به اينكه در اين تحقيق كمينـه شـدن تـابع

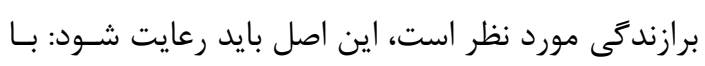

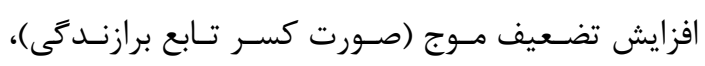

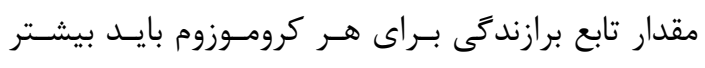

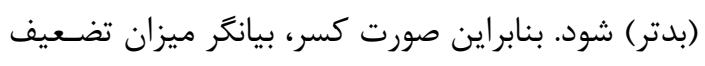

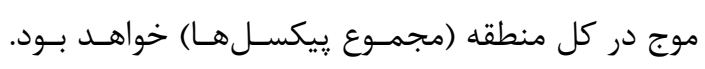

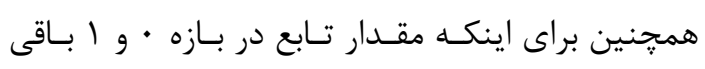

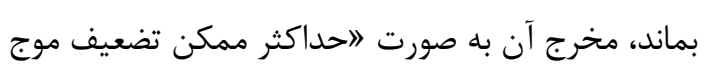
در منطقه" تعريف شد.

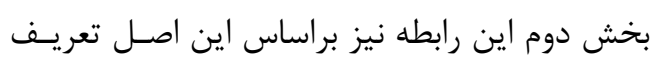

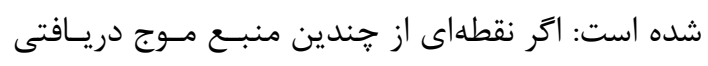




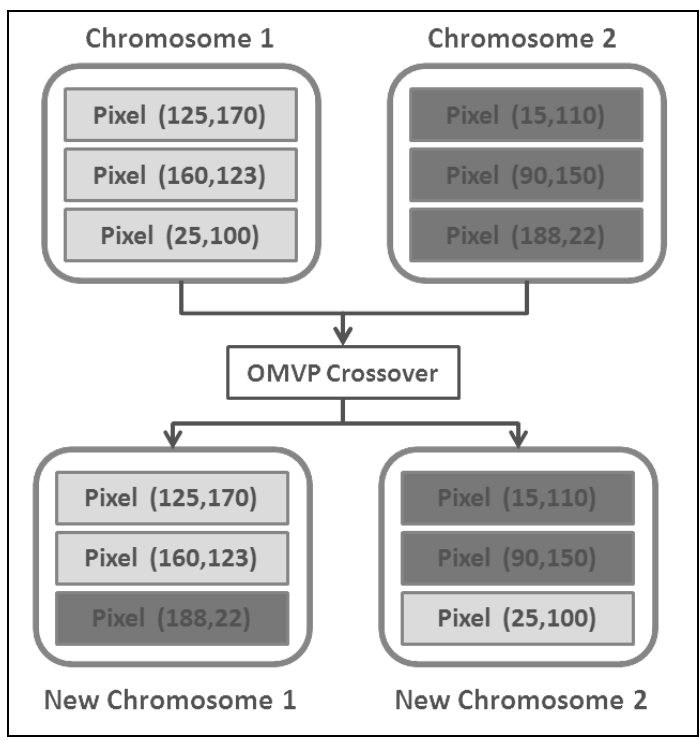

شكل F. فرايند تقاطع كروموزومها در مسئله OMVP

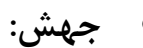

طبق تعريف جهش، مقدار يك رن يا كد منتسب بـ بـ بـه آن

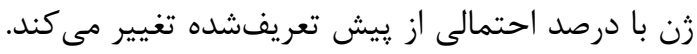

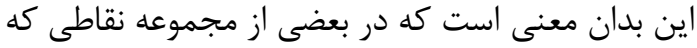

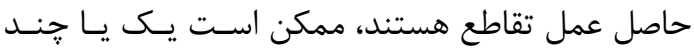

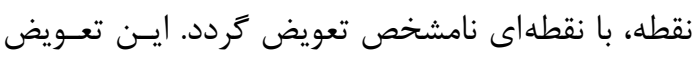

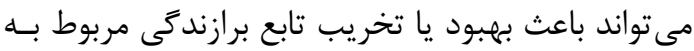
آن مجموعه نقطه كردد.

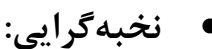

را OMVP مجموعه نقاطى كه بهترين ميزان برازند مئى

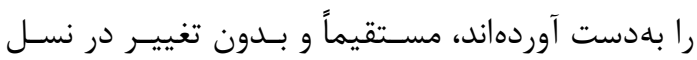

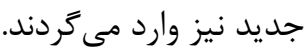

r-Y T- استفاده از TIN به عنوان فضاى جستوجو يكى از مشكلاتى كه هنكام استفاده از الكوريته زينتيـك

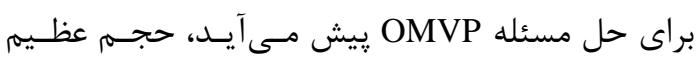

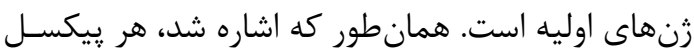

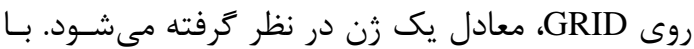

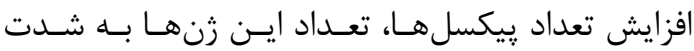

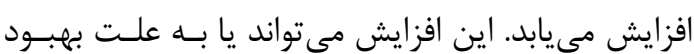

تبع آن نحوه توزيع منابع انتشار)، كيفيت موج دريـافتى

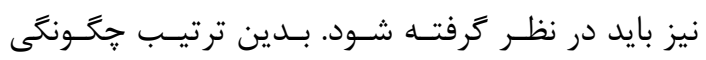

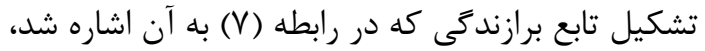

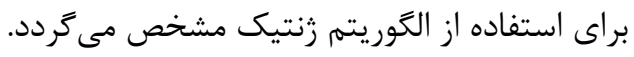

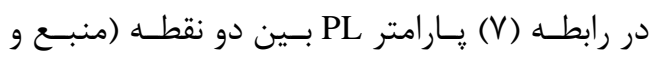

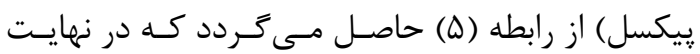

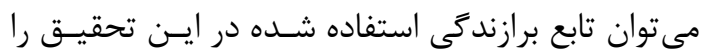
بدين صورت الرائه كرد.

(9) $\mathrm{F}=\frac{\sum_{\mathrm{i}=1}^{\mathrm{m}}\left(32 / 5+1 \log _{10} \mathrm{~d}_{(\mathrm{i})}+2 \log _{10} \mathrm{f}\right)}{\mathrm{m} \times\left(32 / 5+1 \log _{10} \mathrm{~d}_{\max }+2 \log _{10} \mathrm{f}\right)}$

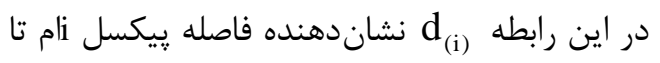

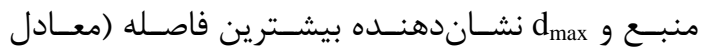

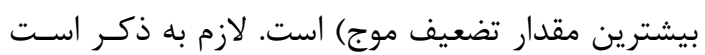

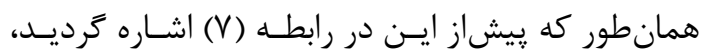

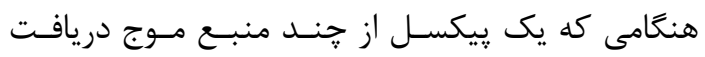

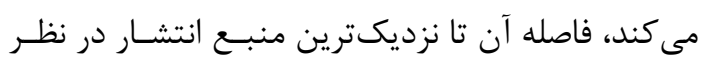

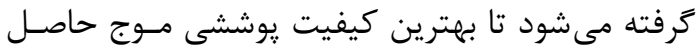

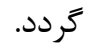

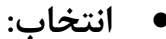

انتخاب كروموزومهاى برتر در مسئله OMVP براسـاس

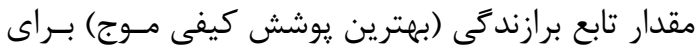

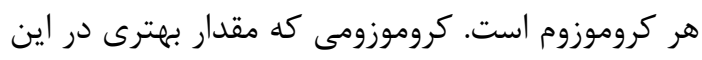

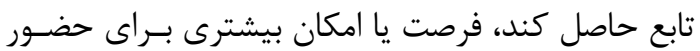

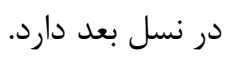

\section{تقاطع:}

در اين تحقيق، تقاطع به معناى جابهجايى نقاط (زنها)

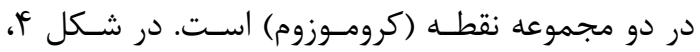

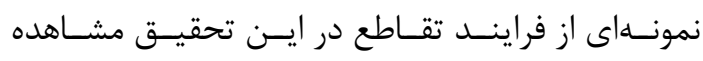
مى تمردد. 
نيست. ساير رييكسل ها در تعيين كيفيت ديد و بـهـ تبـع آن تابع برازندگى ثن ثها و كروموزومها مورد استفاده قرار مى كيرند و اين به معنــاى تلفيـق TIN و رسيدن به بهترين دقت در كمترين زمـان در الحـوريتهم

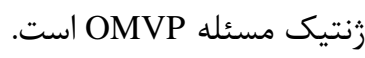

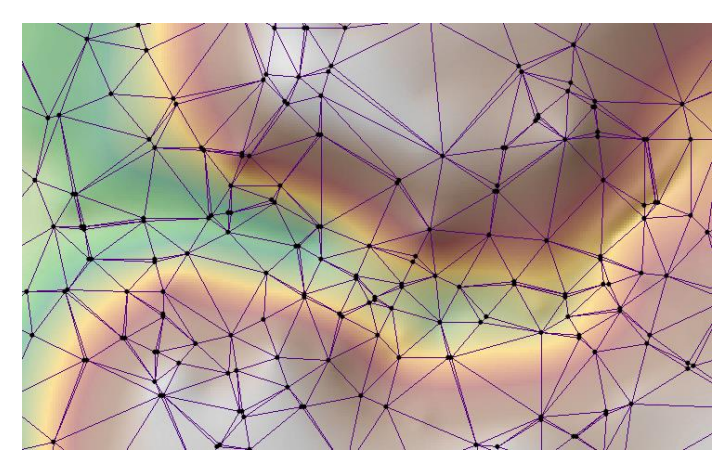

شكل ه. موقعيت رئوس TIN بر روى GRID

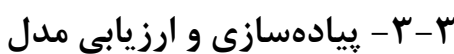

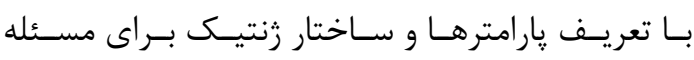

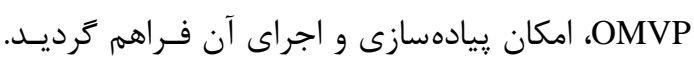
اين ييادهسازى در محيط نرمافززار MATLAB صـورت

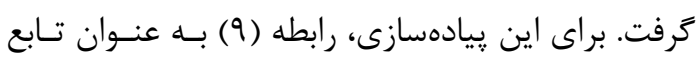

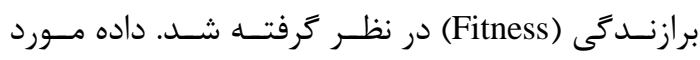
آزمايش نيز منطقـهاى بـا دو قـدرت تفكيـى ها و و •

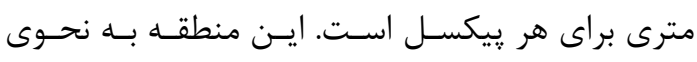

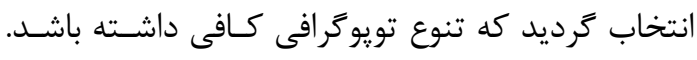
براى هر GRID يك TIN معادل نيـز سـاخته شـد كـهـ مسلماً دقت هر TIN وابسته به قـدرت تفكيك فيك مربوط به آن است. تعداد رئوس TIN حاصـل از هر بـا قـدرت ها متــرى برابـر الها و تعـداد رئسوس TIN

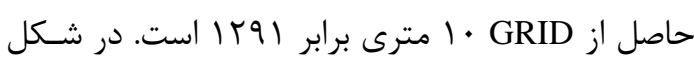

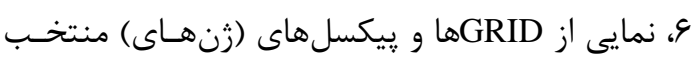
(حاصل از TIN متناظر) نشان داده شده است.

1. Triangulated Irregular Network
دقت GRID و يا به دليل بزرگ شدن ابعاد منطقه باشد

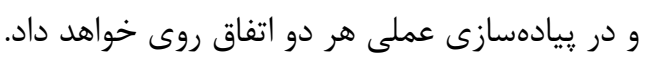
در اين تحقيق براى برطرف شـدن مشـكل مـذكور، بايد روشى اتخاذ مى گرديد كه تعداد زن هاى اوليه برابـر تعداد ييكسل هاى GRID نمى بود و در عمل هر ييكسل

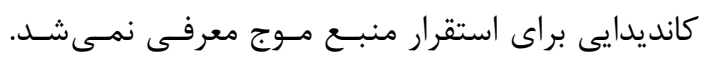

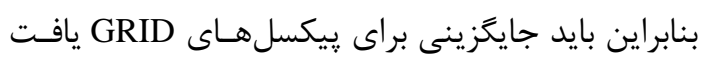

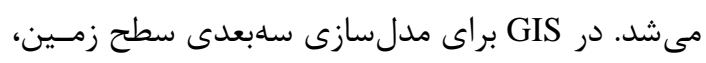

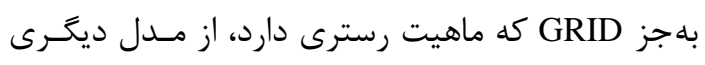

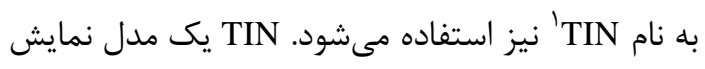

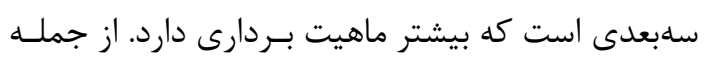

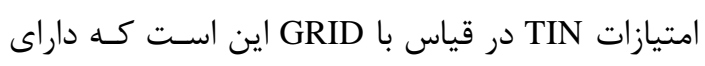
نقاط ويزهاى است كه به كمك اين نقاط شكل زمـين را

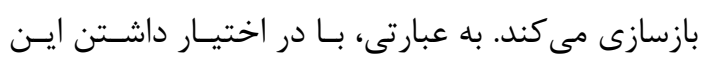
نقاط، مى توان مدلى از شكل سهبعـدى زمــين رازئ رايجـاد

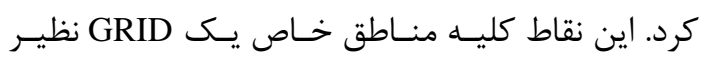

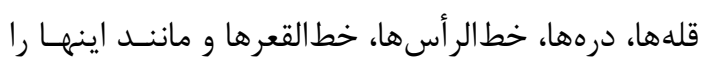

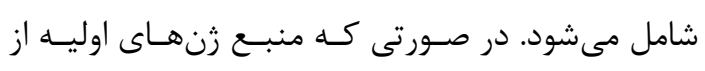

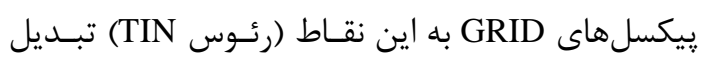

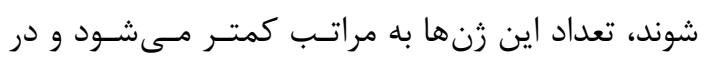
حقيقت، تنها زن هاى داراى اهميت در الكوريتم شركت

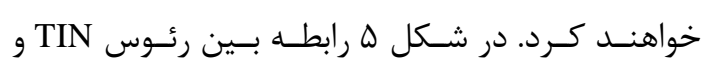
GRID

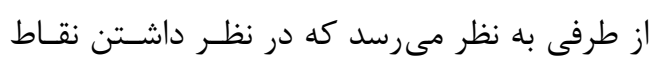

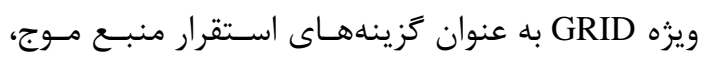
انتخاب درستى است، جرا كه به طور تجربى و در عمـل بـل مشاهده مى شود كه بهترين نقاط ديـد و منـابع انتشـار موج بر روى اين نقاط ويزه (قله، خطالرأس، خطالقعر و

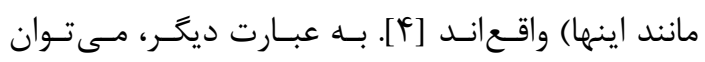

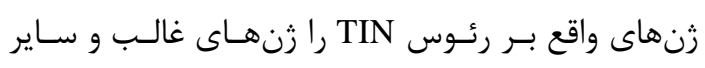

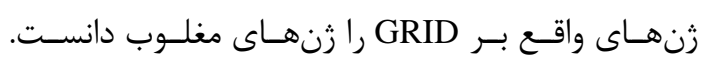

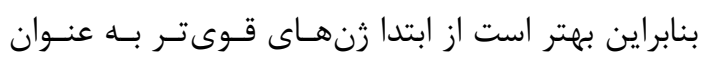

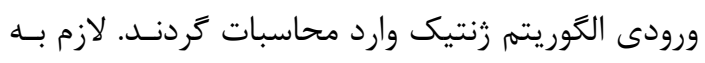
يادآورى است كه انتخاب رئوس TIN به عنوان زنهــاى

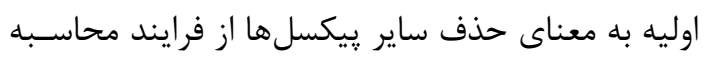




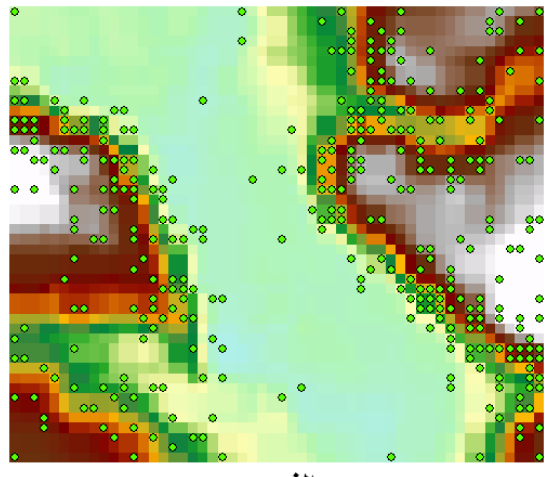

الف

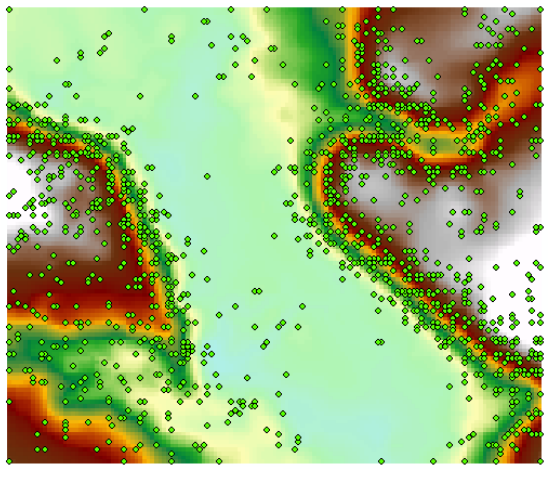

ب

شكل 9. الف) GRID با قدرت تفكيك هY متر و رئوس TIN متناظر

در نهايت اين امكان يديد آمـد كـهـهـ بـا معرفـى هـر

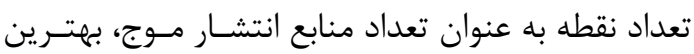

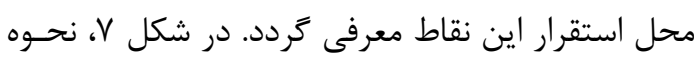

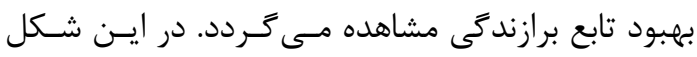
نمودار برازندىى بهترين فرد هر نسل و نمودار ميـانخين

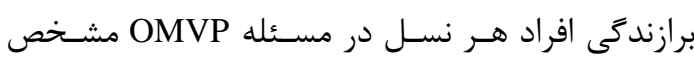

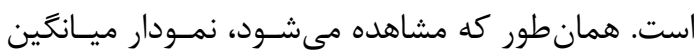

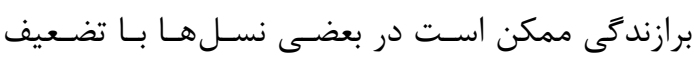

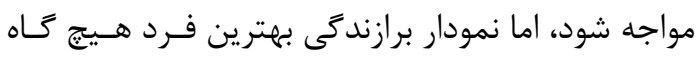

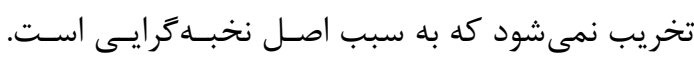

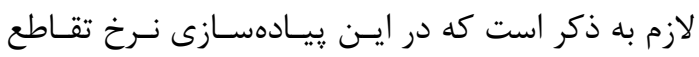

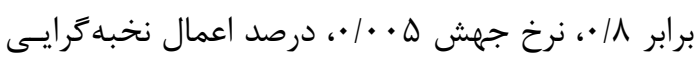

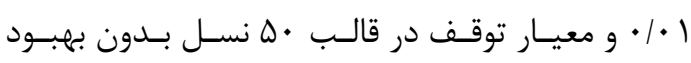
بهترين كروموزوم تعريف گرديد.

در نهايت، در شكل ^ 1 بهترين موقعيت نقاط انتشـار

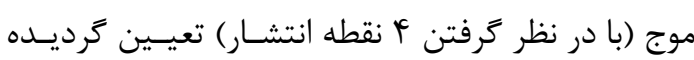

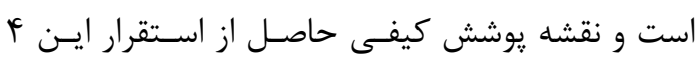

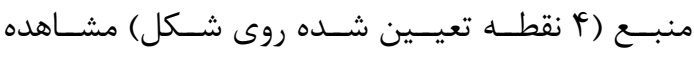

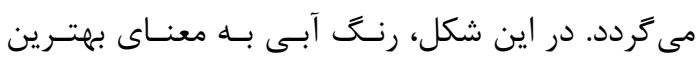

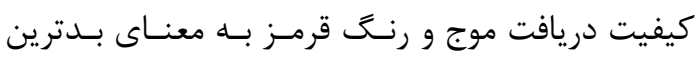
كيفيت موج دريافتى است. مىتوان كفت كه رنخَبندى

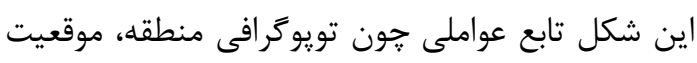

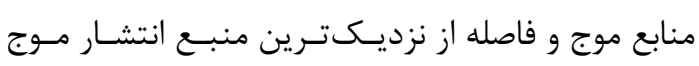
است.
با توجه به اينكــه در GRID بـا قـدرت تفكيـك ها

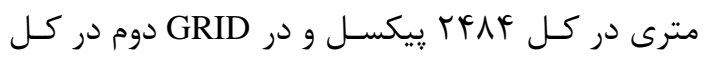
ه D D رئوس TIN در دو حالت اگر تعداد رئوس TIN متنــاظر

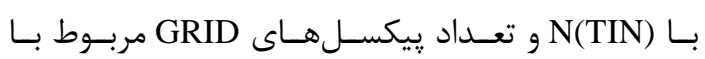
N(DEM)

$\frac{\mathrm{N}\left(\mathrm{TIN}_{25 \mathrm{M}}\right)}{\mathrm{N}\left(\mathrm{DEM}_{25 \mathrm{M}}\right)}=\% / 4$

$\frac{\mathrm{N}\left(\mathrm{TIN}_{10 \mathrm{M}}\right)}{\mathrm{N}\left(\mathrm{DEM}_{10 \mathrm{M}}\right)}=\% 8 / 3$

اين نسبت نشان دهنده نسبت زنهـاى منتخـب بـهـ كل زن هـاى ممكـن اسـت و همـانطـور كـهـ مشـاهده مىشود با افزايش دقت و تعداد ييكسل هـا، ايـن نسـبت كوجى متر مى شود و اين نشاندهنده تأثير روش انتخاب شده در كارايى و سرعت همگرايى الخَـوريتهم زنتيـك در

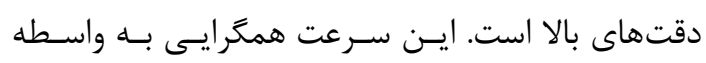

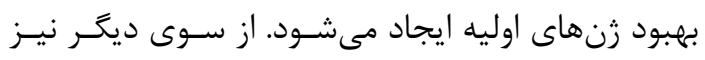

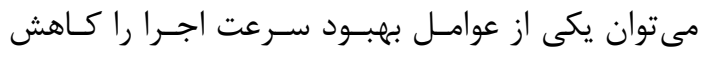

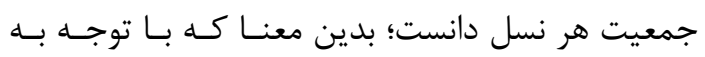

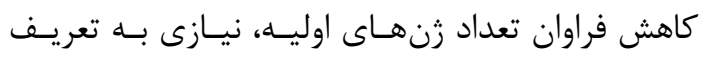
اندازه جمعيت بالا براى يك نسل نيست، جرا كه تعـداد

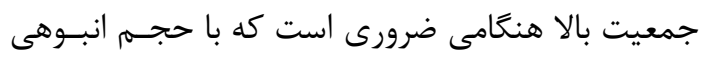

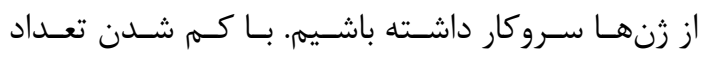
جمعيت، سرعت اجرا افزايش بسيارى بيدا مى كند. 


\section{جينش بهينه منابع انتشار امواج ...}

ابر اهيم اميدى كركانى و همكاران

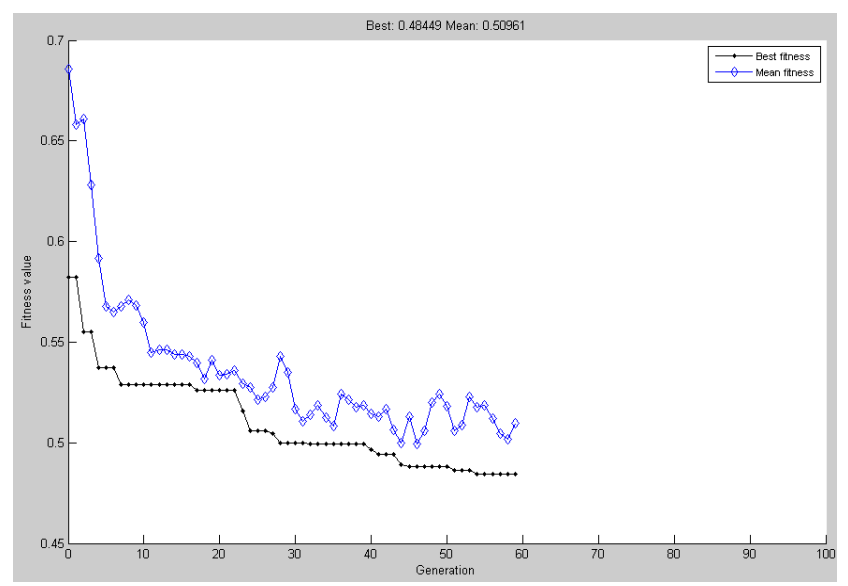

شكل V. نمودار برازندكى بهترين كروموزوم (مجموعه نقاط ديد) و ميانگين برازندَّى هر نسل،

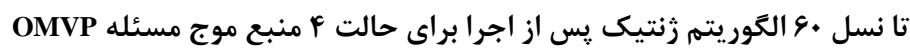

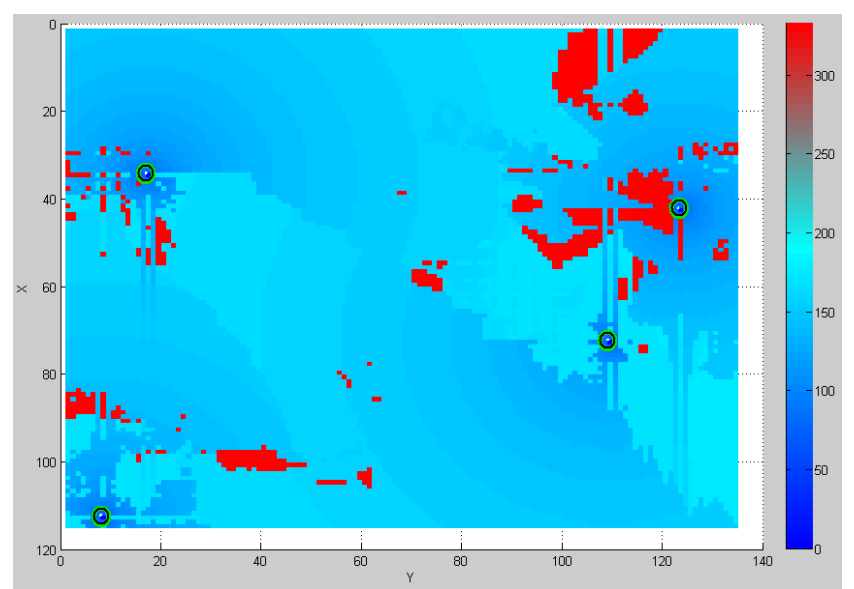

شكل ^، نقشه يوشش كيفى موج با تعيين مكان نقاط استقرار f منبع انتشار (خروجى روش)

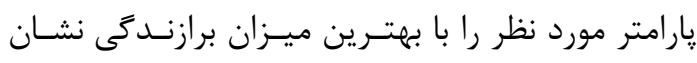

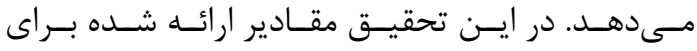

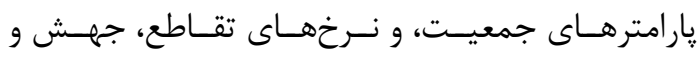

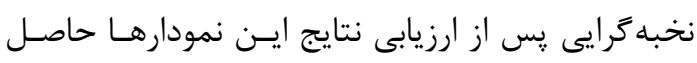
آمد. در شكل 9 اين جهار نمودار نشان داده شده است. همـانطــور كـهـ در نمـودار اول شـكل 9 مشـاهده مى شود، جمعيت كروموزمهاى هر نسل رابطه مسـتقيم

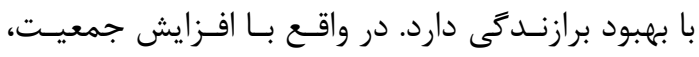

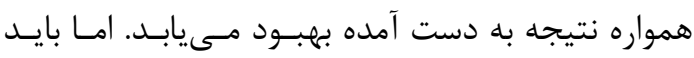

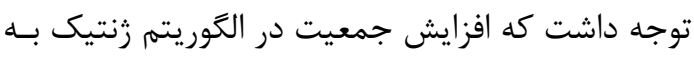

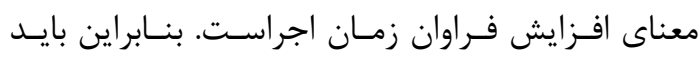

بدين ترتيب به هدف اصلى اين تحقيق، كه رسيدن

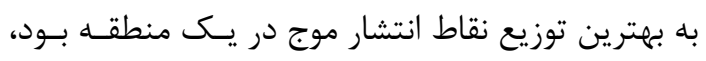

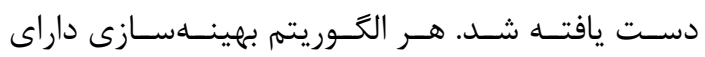

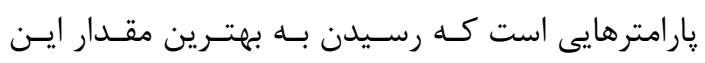

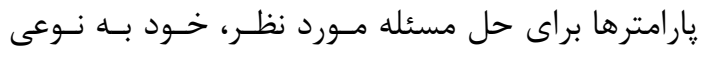

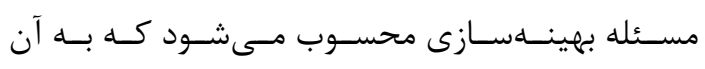

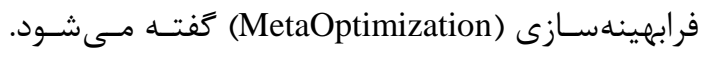
يكى از روشهاى رسيدن به اين بهترين مقادير، آزمـون

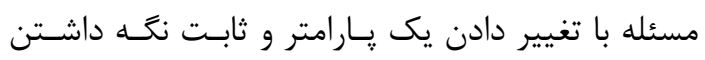

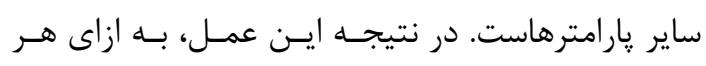

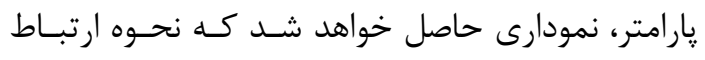




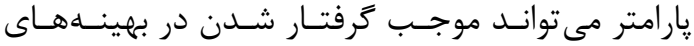

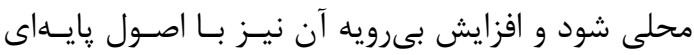
الكوريتم زنتيك (توليد نسل جديد از طريق تركيب) در

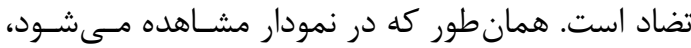

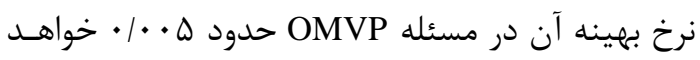

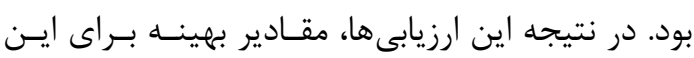
جهار يارامتر بركزيده شد و براسـاس ايسن مقـدار نتـايج نهايى به دست آمد. براى سنجش ميزان كارايى استفاده از رئسوس TIN به عنوان زن هاى منتخب، مقايسهاى صورت كرفت، كـهـ

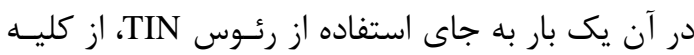

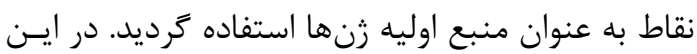
حالت نياز به تعريف تعداد جمعيت بالا براى هر نسل از كروموزومهاست كه باعث كاهش سرعت اجرا و همكرايى الكَوريتم زنتيك است و از طرفى با افزايش تعداد منـابع موج، تعداد تركيبها به صورت نمايى افزايش مسىيابـد كه اين امر نيز به شدت محدودكننده است. در بـار دوم اجرا، از رئوس TIN به عنوان زنهاى اوليه استفاده شــد

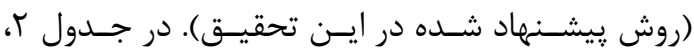
خروجى و نتايج دو روش با هم مقايسه كرديده است.
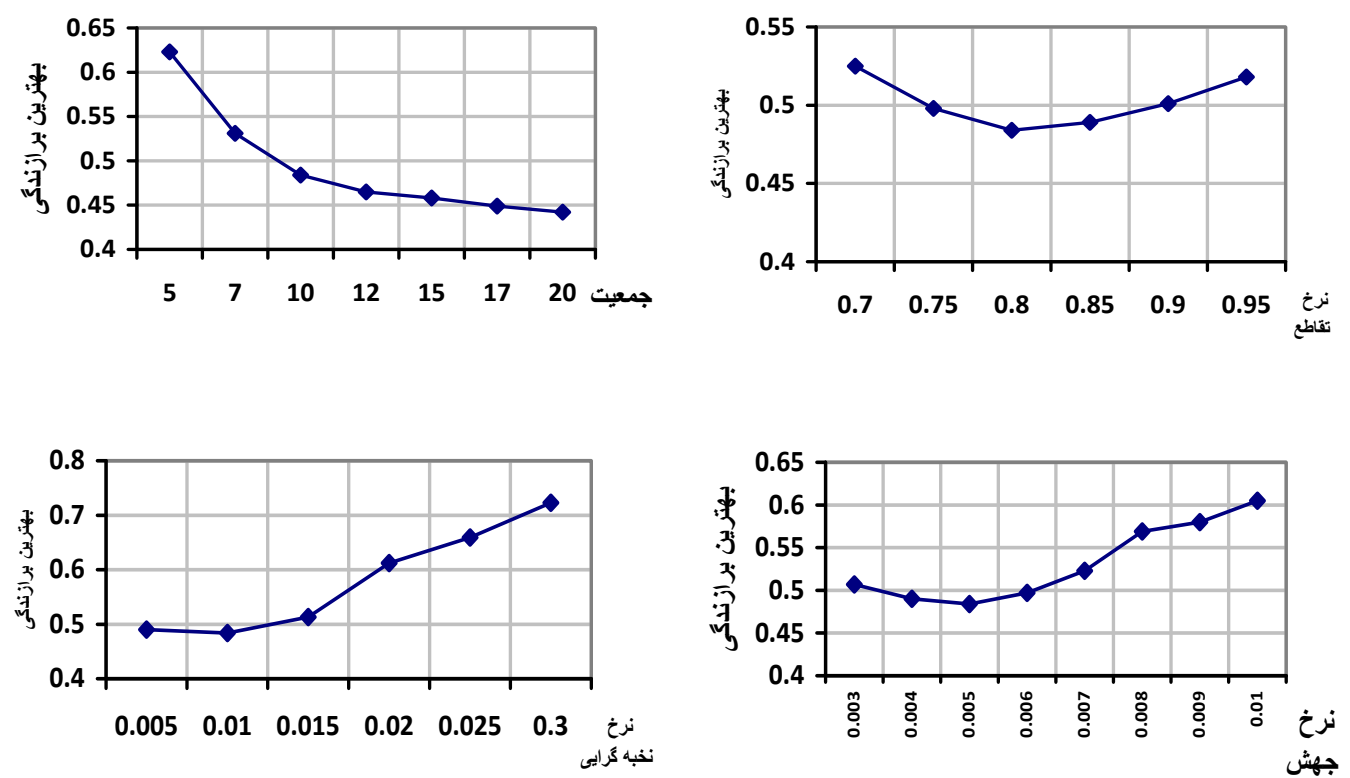

عددى بينابينى انتخاب گردد كه از طرفى نرخ برازندگى

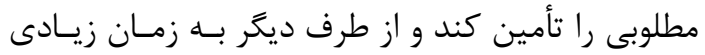
نياز نداشته باشد. بنابراين عدد • ا در ايسن مسـئله، بـهـ عنوان معيار جمعيت هر نسل انتخاب شد.

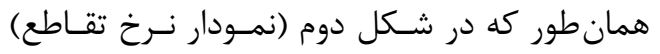
مشخص است، بهترين ميزان اين نـرخ كـهـ باعـث ارائسه

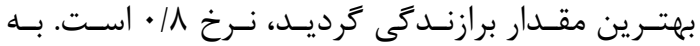

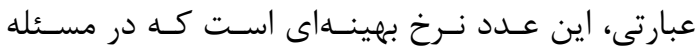
مى توان در نظر داشت. نخبه كرايسى، قـارامترى

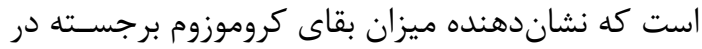

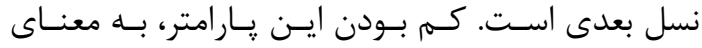

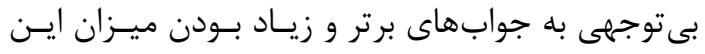

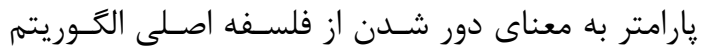
زنتيك (تركيب كروموزومها) است.

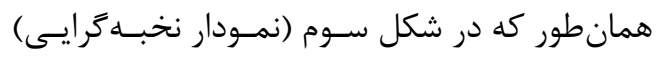
مشخص است، عدد بهينه براى اين مقدار 1 •|• خواهـــ

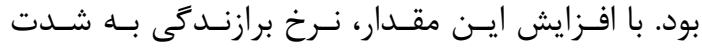

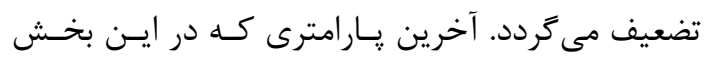
مورد ارزيابى قرار كرفت، نرخ جهش است كه ايـن نـرخ

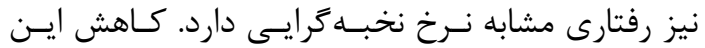

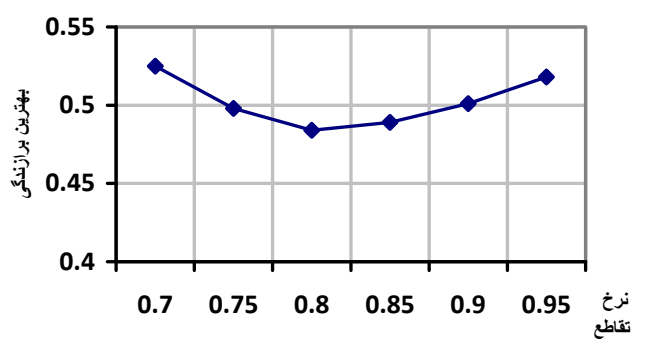

جهش

شكل 9. ارزيابى نحوه تأثير هارامترهاى مختلف الكوريتم زنتيك بر عدد برازندكى 
جدول r. برترى نتايج حاصل از روش بركزيدن زنهاى برتر به كمك TIN نسبت به روش معمولى در مسئله OMVP

\begin{tabular}{|c|c|c|c|c|}
\hline ميانغين برازندكى & بهترين برازندكى & زمان اجرا (ثانيه) & تعداد جمعيت هر نسل & $\begin{array}{c}\text { روش استفاده از زنتيك در مسئله } \\
\text { OMVP }\end{array}$ \\
\hline - IOTD & $\cdot 10$ & FN/V & $\Delta \cdot$ & بدون تلفيق TIN \\
\hline$\cdot 10 \cdot 9$ & $\cdot / 4 \wedge F$ & $1 T / \pi$ & $1 \cdot$ & بركزيدن زنهاى برتر به كمك TIN \\
\hline
\end{tabular}

عمـل نـاممكن اسـت. بنــابراين در ايــن تحقيـق از روشهاى بهينهسازى عددى از نوع تصادفى استفاده شد و در اين ميان ساختار الخوريتم زنتيك بيشترين

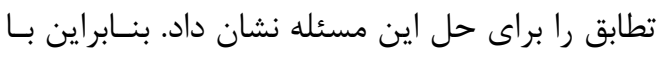
تعريف اجزاى الخوريتم زنتيك براى مسئله OMVP، امكان يافتن بهترين جينش فراهم آمد. در اين ميان يكى از اجزاى اصلى، تابع تناسب (Fitness) است كه ئنس

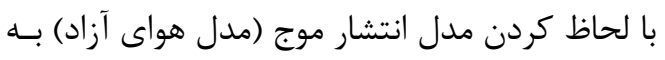

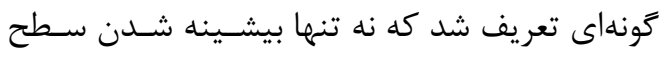

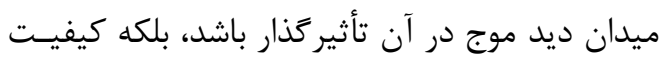
موج دريافتى نيز يكى از يارامترهاى اصلى در مقــدار

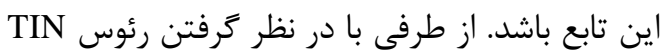

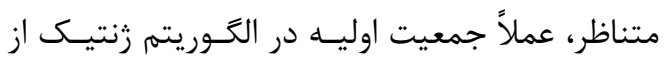
تعداد كل ي يكسلهاى GRID به تعـداد رئسوس TIN

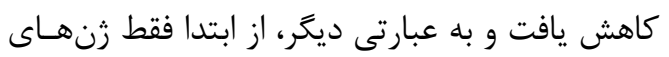
قوى در اين رقابت دخالت داده شدند. در نتيجه اين عمليات مـدلى بــر پايـهـ الخــوريتهم زنتيك حاصل گرديد كه بهترين نقاط استقرار منــابع

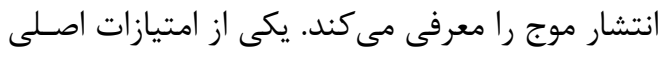

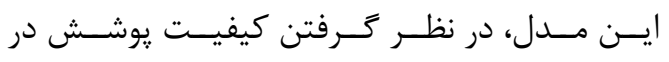
محاسبات است و امتياز مهرم ديخر قابليت بيادهسازى آن در مقياس واقعى به واسـطه تلفيـق مـدل TIN و GRID مدلهاى جامعترى از يديده تضعيف موج كه در آنها

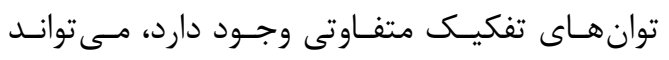

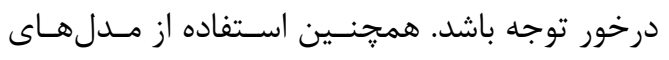

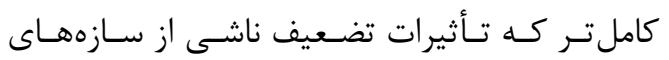

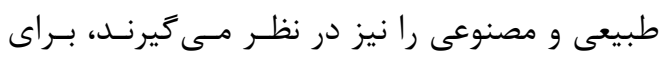

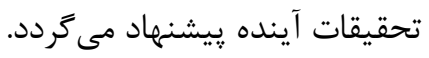

همان طور كه مشخص است، بـا وجـود بـالاتر بـودن بيش از حد جمعيت هر نسل و بالا رفتن جند برابر زمان

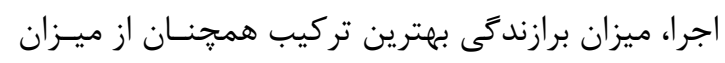

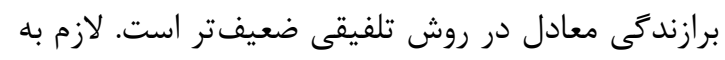

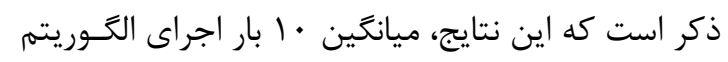
براى هر حالت است. يادآورى مىشود كه در اجراى ايسن ائن

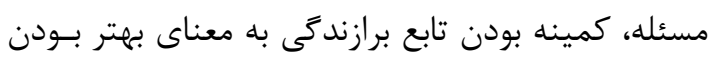

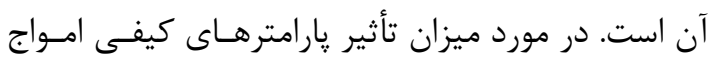

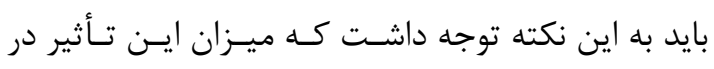
عمل به حداقل كيفيـت مطلـوب مـوج دريـافتى در هـر فر كانس بستخى دارد. به دليل اينكه اين تحقيق، به طور

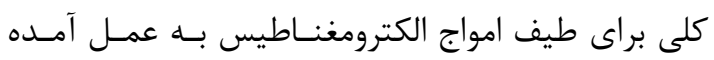

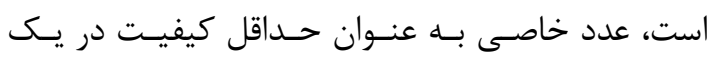

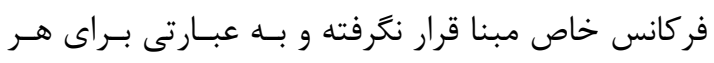

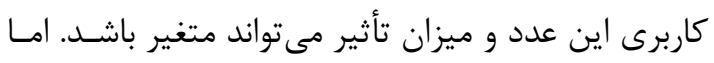
در حالت كلى، مطابق رابطه (ه)، مى توان كفت كه مين ميزان

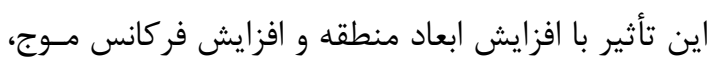

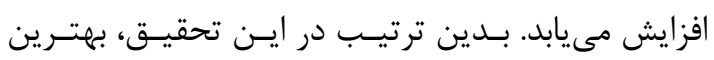

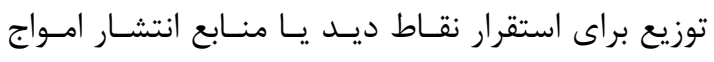

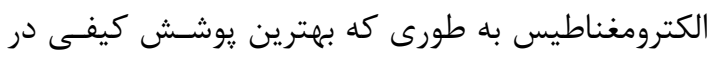

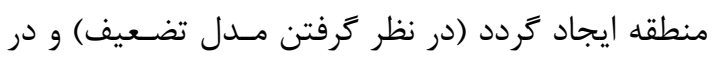

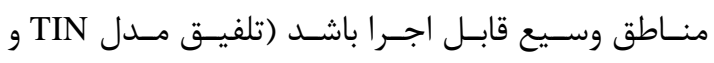
(GRID

\section{F - نتيجه Fيرى و ييشنهادها}

مهرمترين هدف اين تحقيق يافتن بهترين جيــنش نقـاط

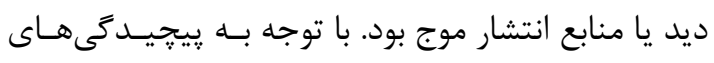

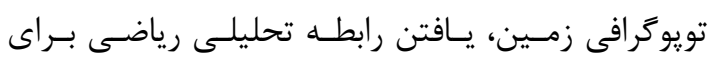

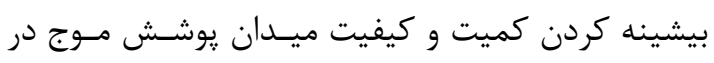


Algorithm for Designing Optimized Cellular GSM networks. In: 13th Conference of Computer Society of Iran, Kish, Iran. (Persian)

[7] Rappaport T.S., 2002. Wireless Communications Principles and Practices. New Jersey: Prentice-Hall.

[8] Burrough, P.A. and McDonnel, R.A., 1998. Principles of Geographical Information Systems. London: Oxford University Press, 346 pp.

[9] Fisher, P.F., 1996. Extending the Applicability of Viewsheds in Landscape Planning. Photogrammetric Engineering \& Remote Sensing, 62 (11), 1297-1302.

[10] Bavari, O. and Salehi, M., 2008. Genetic Algorithms and Optimization of Composite Structures. Iran: Abed Press (In Persian language), 200 pages.

[11]Das A., and Chakrabarti, B.K., eds. 2005. Quantum Annealing and Related Optimization Methods. Lecture Note in Physics, 679, Heidelberg: Springer.

[12] Bies, Robert, R., Muldoon, Matthew, F., Pollock, Bruce, G., Manuck, Steven, Smith, Gwenn and Sale, Mark, E., 2006. A Genetic Algorithm-Based, Hybrid Machine Learning Approach to Model Selection. Journal of Pharmacokinetics and Pharmacodynamics, 33(2), 196-221.

[13] Poli, R., Langdon, W.B. and McPhee, N. F., 2008. A Field Guide to Genetic Programming. Uk: Lulu Enter prises.

[14]Pedersen, M.E.H. and Chipperfield, A.J., 2010. Simplifying Particle Swarm Optimization. Applied Soft Computing 10, 618-628.

[15] National Communications System Technology \& standard Division, 2000. Telecom Glossary 2000. http://www.its.bldrdoc.gov/projects/devgl ossary/, http://en.wikipedia.org/wiki/Path_loss, Accessed September 2009.

[16] AIRCOM International, 2002. GSM System Overview, London: Crosvenor House press (Technical Report).

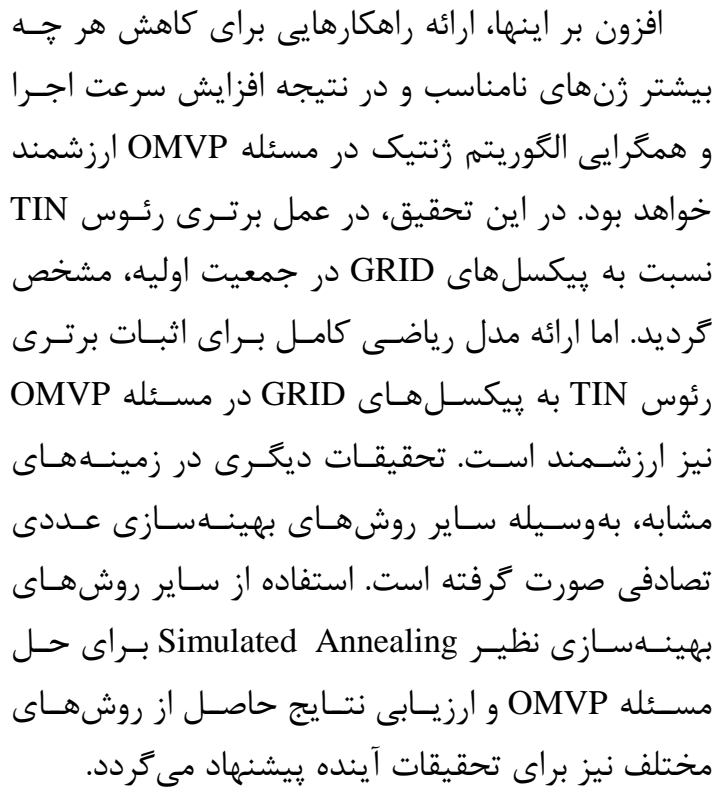

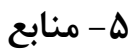

[1] De Floriani, L., Marzano, L. and Puppo, P.E., 1994. Line-of-sight Communication on Terrain Models. International Journal of Geographical Information Systems, 8 (4), 329-342.

[2] Mattikalli, R., Fresnedo, R., Frank, P., Locke, S.,Thunemann, Z., 2007. Optimal Sensor Selection and Placement for Perimeter Defense. In: 3rd Annual IEEE Conference on Automation Science and Engineering Scottsdale, AZ, USA.

[3] Kidner, D., Sparkes, A. and Dorey, M., 1999. GIS and Wind Farm Planning. In: J. Stillwell, S. Geertman, S. Openshaw, eds. Geographical Information and Planning. London: Springer, 203-223.

[4] Kim, Y.H., Rana, S., Wise, S., 2004. Exploring Multiple Viewshed Analysis using Terrain Features and Optimisation Techniques. Computers \& Geosciences, 30, 1019-1032.

[5] Rana, S., 2003. Fast Approximation of Visibility Dominance Using Topographic Features as Targets and the Associated Uncertainty. Photogrammetric Engineering and Remote Sensing, 69 (8), 881-888.

[6] Qoraishi, N., Mohammadi, M., Robatmaily, M. and Fathi, M., 2007. A New Genetic 


\title{
Optimal Spatial Distribution of Sources of Electromagnetic Wave Propagation for Acquiring Best Qualitative Coverage (Using Genetic Algorithms in GIS)
}

\author{
Omidi Garakani Eb. ${ }^{1}$, Mansourian A. ${ }^{2}$, Mesgari M.S. ${ }^{2}$, Omidi Garakani Eh. ${ }^{3}$ \\ 1- Ph.D. Candidate in GIS. Geodesy \& Geomatics Faculty, K.N. Toosi University of Technology \\ 2- Assistant Prof., GIS Dep., Geodesy \& Geomatics Faculty, K.N. Toosi University of Technology \\ 3- B.Sc. Student, Amirkabir University of Technology
}

\begin{abstract}
Optimal multiple viewpoints problem (OMVP) is an optimization problem, which could not be solved by using analytical methods, since there is not any distinct mathematical relationship between the positions of viewpoints and combinatorial viewshed. Due to the variety of applications of OMVP in communications, surveying, military, urban planning, etc., it is necessary to find a solution. Current solutions include many shortcoming, and disadvantages such as: "not considering the quality of coverage (quality of the received signal)" and "not being applicable because of high number of calculations". In this paper, a new genetic method has been used to solve OMVP which resolves the mentioned shortcomings, considerably. In this method, each viewpoint is considered as a gene and each $\mathrm{N}$ viewpoint compose a chromosome. The quality problem is solved by considering electromagnetic wave attenuation model as the fitness function. The number of calculations has also been considerably reduced by integrated utilization of DEM and TIN, Were TIN vertices are used as the first genes instead of DEM pixels. The results of the practical test showed the flexibility and applicability of the proposed method for OMVP.
\end{abstract}

Keywords: Viewshed, Wave propagation model, Optimal multiple viewpoints problem (OMVP), Wave attenuation, Genetic algorithm, Optimization, TIN.

* Correspondence Address: 1364, Valiasr street, Mirdamad intersection, Tehran, Iran. Tel: 021-77907111. 